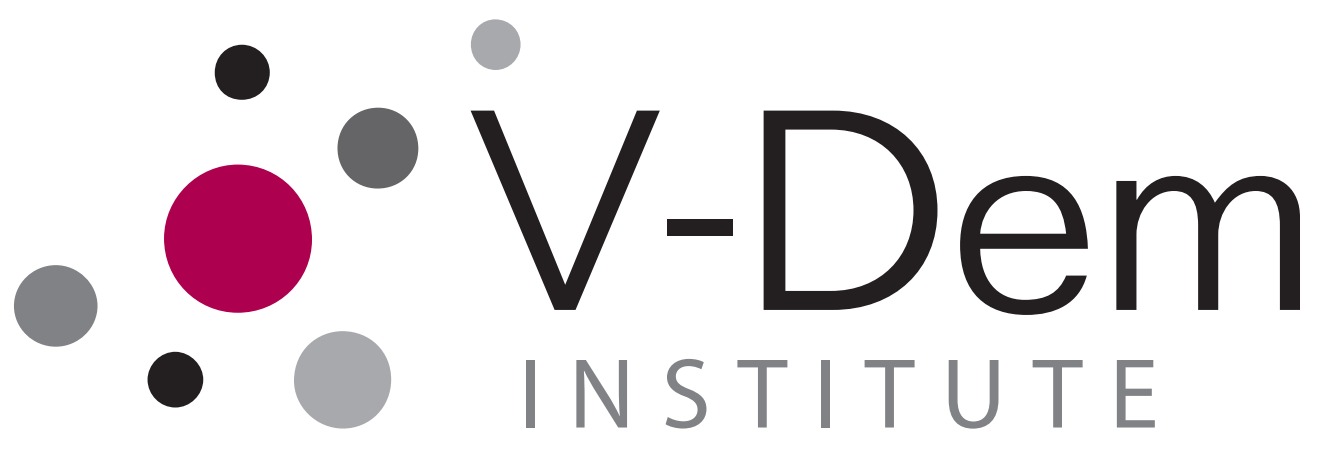

00000000000000000000

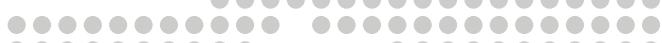
80 -

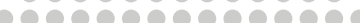

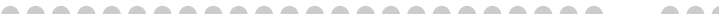

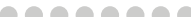

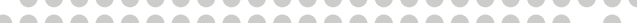
o

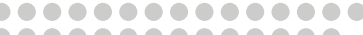
00000000000000 $\operatorname{sen}$ 800 10000000000 0000000000 (2000000 0000000

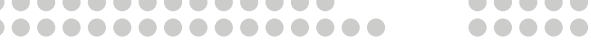
\%0000000000000000 000000

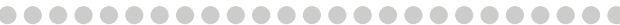

\title{
Local Democracy and Economic Growth
}

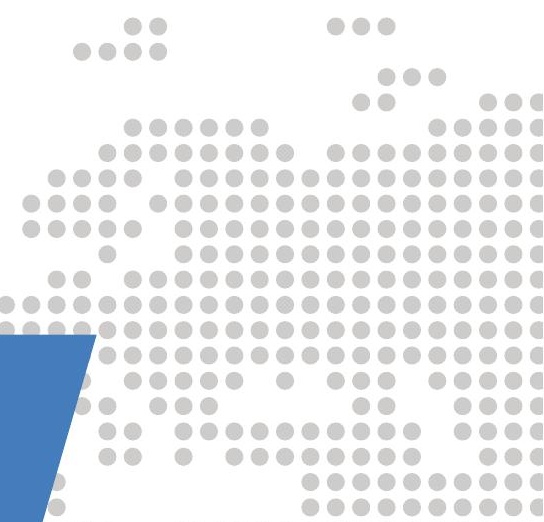

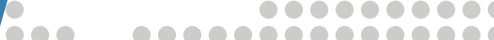

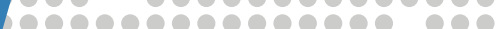

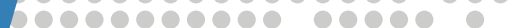

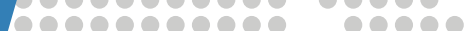

Carl Henrik Knutsen, John Gerring, Svend-Erik Skaaning

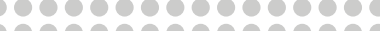

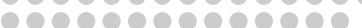

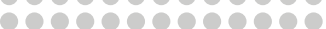
00000000000
00000000000

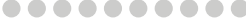

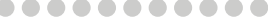
000000000

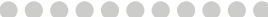

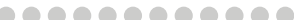

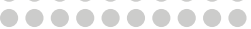
6ер08908
0000000 000000
- 00000
00000
1000
(1009

00000000

100000

000000

000000

100000

000

100

10

10

0

0

November 2016

\section{Working Paper}


Varieties of Democracy (V-Dem) is a new approach to the conceptualization and measurement of democracy. It is co-hosted by the University of Gothenburg and University of Notre Dame. With a V-Dem Institute at University of Gothenburg that comprises almost ten staff members, and a project team across the world with four Principal Investigators, fifteen Project Managers, 30+ Regional Managers, 170 Country Coordinators, Research Assistants, and 2,500 Country Experts, the V-Dem project is one of the largest-ever social science researchoriented data collection programs.

Please address comments and/or queries for information to:

V-Dem Institute

Department of Political Science

University of Gothenburg

Sprängkullsgatan 19, PO Box 711

SE 40530 Gothenburg

Sweden

E-mail: contact@v-dem.net

V-Dem Working Papers are available in electronic format at www.v-dem.net.

Copyright (C) 2016 by authors. All rights reserved. 


\title{
Local Democracy and Economic Growth ${ }^{*}$
}

\author{
Carl Henrik Knutsen \\ Professor of Political Science \\ University of Oslo \\ John Gerring \\ Professor of Political Science \\ University of Texas at Austin \\ Svend-Erik Skaaning \\ Professor of Political Science \\ Aarhus University
}

\begin{abstract}
- This research project was supported by Riksbankens Jubileumsfond, Grant M13-0559:1, PI: Staffan I. Lindberg, VDem Institute, University of Gothenburg, Sweden; by Knut and Alice Wallenberg Foundation to Wallenberg Academy Fellow Staffan I. Lindberg, Grant 2013.0166, V-Dem Institute, University of Gothenburg, Sweden; as well as by internal grants from the Vice-Chancellor's office, the Dean of the College of Social Sciences, the Department of Political Science at University of Gothenburg; and the University of Florida Foundation in support of the Miriam and Raymond Ehrlich Eminent Scholar Chair in Political Science. We performed simulations and other computational tasks using resources provided by the Notre Dame Center for Research Computing (CRC) through the High Performance Computing section and the Swedish National Infrastructure for Computing (SNIC) at the National Supercomputer Centre in Sweden. We specifically acknowledge the assistance of In-Saeng Suh at CRC and Johan Raber at SNIC in facilitating our use of their respective systems. We thank Aníbal Pérez-Liñán, Michael Miller, Zdravko Petak, Michael Ting, Jan Teorell, participants at the 2016 APSA Annual Meeting in Philadelphia, 2016 IPSA Conference in Poznan, 2016 EPSA Annual Conference in Brussels, 2016 Danish Annual Political Science Conference in Velje, and the 2016 V-Dem Conference in Gothenburg for valuable comments and suggestions. We want to especially thank Tore Wig for comments and others throughout the process. Knutsen's work on this project was funded by Research Council Norway Grant pnr 240505.
\end{abstract}




\section{Abstract}

Theoretical work on the institutional sources of economic growth regards decentralization and democracy in a positive light. Despite this, empirical work shows that neither fiscal decentralization nor national democracy is a robust predictor of per capita GDP growth. We argue that these theories have failed to bear fruit because they ignore the linchpin of decentralization and democracy, namely local democracy. Democracy at a local level enhances economic growth by enabling decentralized policy selection and incentivizing local politicians to select policies that benefit economic development, including the provision of local public goods. We test for the relationship using a novel measure of local democracy with global coverage and time series extending from 1900 to the present. We find robust evidence that local democracy nurtures growth. This relationship holds up when accounting for country- and year-fixed effects, when controlling for democracy at the national level, and when we treat our measure of local democracy as an endogenous regressor. Additional tests reveal that the relationship is clearer in contexts where our argument suggests that it should operate more strongly, namely (nationallevel) democracies and in periods and regions where local-level institutions have a more pronounced role in policy-making. 


\section{Introduction}

Those who believe that institutions matter for economic performance often focus on two principles of institutional design. The first is decentralization, variously conceptualized as constitutional federalism, fiscal federalism, or local governance (Bardhan 2002; Bardhan and Mookherjee 2006; Besley and Coate 2003; Faguet and Pöschl 2015; Inman and Rubinfeld 1997; Oates 1972; Tiebout 1956; Treisman 2007; Weingast 1995). The second is democracy, variously understood according to electoral or liberal conceptions of that protean concept (Acemoglu, Naidu, Restrepo, and Robinson 2015; Barzel 2002; Bueno de Mesquita and Root 2000; Gerring, Bond, Barndt, and Moreno 2005; Knutsen 2012; Oppenheimer and Edwards 2012; Przeworski et al. 2000; Wittman 1995). Yet, despite the large body of theoretical and empirical work that has accumulated on these subjects, scholars are not agreed upon how, whether, or under what conditions these institutional features affect economic performance.

With respect to decentralization, theoretical arguments often center on the notion that local-level actors have better information about what constitutes the most effective policies in particular local contexts. Counter-arguments highlight that local actors may not have the power, in practice, to truly shape local policy, that local-level decision making (as national-level) may be associated with agency problems, and that decentralized policy-making often entails coordination problems at the national level that may mitigate development (see Bardhan 2002; Faguet and Pöschl 2015; Mookherjee 2015). Recent reviews of the empirical literature report mixed results (Gemmell, Kneller, and Sanz 2013; Hankla 2009; Hankla and Downs 2010; Martinez-Vazquez and McNab 2003). A meta-analysis conducted by Baskaran, Feld, and Schnellenbach (2016) shows that the relationship is highly sensitive to choices in specification, estimator (e.g., with or without country fixed-effects), and sample. Note that the panels employed in these cross-country analyses are centered on the OECD and include less than 75 countries. The temporal range is also limited, as no study extends back further than 1970 - a problematic feature when the rightside variables of interest are sluggish. Most importantly, the concept of decentralization is usually operationalized as fiscal decentralization (i.e., share of total revenue or expenditure collected by subnational authorities), a measure that is far from perfect since subnational authorities are not always free to allocate revenue as they see fit. Fiscal decentralization should not be equated with political decentralization (Rodden 2004; White 2011).

With respect to regime type, theories generally predict that democracies should have higher growth, e.g., because policy-makers should be disciplined by competitive elections to provide policies that benefit the wider population rather than serving the leader's personal 
interests. Yet, if the presumed accountability mechanisms generated by competitive national elections are flawed, as discussed below, national democratic leaders may not be incentivized to pursue growth-enhancing policies. The empirical verdict is mixed. A few recent studies find a positive relationship between democracy and per capita GDP growth (e.g., Acemoglu et al. 2015; Gerring et al. 2005; Knutsen 2015). Others conclude that countries with authoritarian polities grow about as rapidly as democracies with similar background conditions or that the relationship is contingent on different contextual features and therefore highly sensitive to model specification (e.g., Alesina and Perotti 1997; Barro 1996; Brunetti 1997; Dawson 1999; De Haan and Siermann 1995a, 1995b; Doucouliagos and Ulubasoglu 2008; Faust 2007; Feng 1997, 2003; Gasiorowski 2000; Giavazzi and Tabellini 2005; Hausmann, Pritchett and Rodrik 2005; Helliwell 1994; Krieckhaus 2004; Kurzman, Werum, and Burkhart 2002; Norris 2012; Przeworski and Limongi 1993; Przeworski et al. 2000; Tavares and Wacziarg 2001).

We argue that both decentralization and democracy depend upon the democratization of local institutions. Local democracy is thus the linchpin of decentralization and democracy. Decentralization enables local actors with informational advantages to pick the most appropriate policies, and free and fair elections at the local level ensure that these actors are incentivized to do so. Both the capacity to identify the right policies and the incentives to pursue those policies - in areas such as infrastructure, education, property rights protection, and business regulation - are requisites for economic growth. Hence, we propose that growth is enhanced when policymaking institutions at the local level are elective and subject to robust multi-party competition.

The remainder of the paper proceeds as follows. First, we lay out our theoretical argument. Second, after briefly reviewing extant work on local democracy, we present our data and discuss issues of research design. This study benefits from a carefully constructed measure of local democracy with unprecedented global and historical coverage drawn from the Varieties of Democracy (V-Dem) project (Coppedge et al. 2016). Third, we conduct crossnational panel regressions that employ measures of decentralization, democracy, and local democracy as predictors of growth. These analyses show that only the latter is a robust predictor of subsequent economic performance. Fourth, we expose the relationship between local democracy and growth to a variety of additional tests. Fifth, we examine alternate measures of local (and subnational) democracy. Sixth, we interrogate the relationship between local democracy and growth in specific institutional, geographic, and temporal contexts. And finally, we summarize our findings and point the way to future research. 


\section{Theory}

In the search to identify "good institutions" theories of decentralization have centered on national/subnational relationships while theories of democracy have centered on national-level institutions. Our theory combines elements of both, centering on local democracy. This is defined as a setting in which the most important policy-making bodies at subnational levels are chosen through free and fair elections. ${ }^{1}$

The argument builds on three assumptions: (1) political decentralization is very hard to achieve, in practice, without local democracy; (2) policies selected at the local level matter for growth; and (3) local democracy establishes local-level accountability, which incentivizes local politicians to provide public goods. We discuss these assumptions, in sequence, before summarizing the empirical implications that follow from the argument.

(1) Political decentralization is generally understood as the devolution of political power from center to periphery, which entails the possibility for local actors to select policies in various areas. ${ }^{2}$ Yet the ideal of political decentralization is difficult to achieve, in practice, even if the rights of subnational actors are constitutionally guaranteed and they possess revenue-raising authority. Officials at the center may incentivize local actors by promising monetary rewards to localities that follow their lead; they may utilize legal precedents to reinterpret constitutional principles; and they may reward loyalty with higher-level appointments. Typically, the central government, or its agents (e.g., a dominant party), controls the fates of ambitious politicians and bureaucrats. In this circumstance it matters little what constitutional, statutory, or fiscal policies are in effect. If subnational officeholders are beholden to national officeholders there will be very tenuous or little effective decentralization of power, as, for instance, the experiences of “political recentralization” in Russia under Putin illustrates (Konitzer and Wegren 2006).

To counter the centripetal force of central government, local institutions must have local ballast. Local democracy serves this function, for elective officials are then accountable to a local electorate, whose concerns may be quite different from leaders at the center, or from the

\footnotetext{
${ }^{1}$ We focus on local-level (county or municipal) institutions rather than regional-level (state, territory, länder) institutions, as we regard the former as more important in most contexts - though perhaps not in federal nationstates. In our empirical analysis we do test indices incorporating characteristics of regional entities and evaluate the relative importance of democracy at the regional and local levels in enhancing growth.

${ }^{2}$ Of course, if the center is very weak - at the limit, a failed state - then power is devolved by default. This is abdication, not decentralization, and is unlikely to foster economic prosperity, as suggested by literature on the performance of weak or failed states (Acemoglu 2005; Bates 2008). Political decentralization implies that power is willfully granted from center to periphery and could be retrieved if the central government mustered its full strength. Brakes on the central government are thus political (as in the United States), not military (as in present-day Somalia). We therefore assume that the central government enjoys an effective monopoly on coercion and can overcome coercive apparatuses wielded by subnational units.
} 
national electorate. ${ }^{3}$ Thus, we conclude that significant decentralization of policy-making responsibilities is difficult to achieve unless local democracy is in place.

(2) Political decentralization can matter for economic development, as it provides local policy makers with influence over decision-making in areas that critically shape the expected incomes, costs and risks for workers, investors, and entrepreneurs. This includes activities that affect entry and competition between businesses, such as implementing zoning and building regulations, and providing public goods and services such as primary and secondary education, health care, sanitation, public assistance, law and order, controlling small-scale corruption, and regulation of property rights (Dickovick 2011; Haider-Markel 2014).

Policies in some of these areas, including education, have a fairly direct impact on human capital, which growth economists consider a key determinant of (at least) medium-run growth (Mankiw, Romer, and Weil 1992; Acemoglu 2009). While national governments may determine the broad outlines of education policy, local governments often run the schools. Their actions affect the provision of school equipment, the quality of buildings, and the hiring of teachers (Haider-Markel 2014). These aspects of the education system are critical for education quality (see, e.g., Stasavage 2005), which is a more important determinant of human capital than, e.g., the number of years that kids stay in school (e.g., Hanushek \& Woessmann 2008, 2012; Jamison, Jamison, and Hanushek 2007). Other policies implemented at the local level, pertaining for example to monitoring property rights and controlling corruption, affect physical capital investment (North 1990; Shleifer and Vishny 1993), another key determinant of medium-term growth (Solow 1956; Acemoglu 2009). ${ }^{4}$ It is therefore plausible to suppose that the capacity of local governments to, e.g., select effective regulatory policies and deliver public goods influences a country's per capita growth over the long-term.

While the policy-making role of local government is not incidental anywhere, which policy areas are (largely) the responsibility of national-level and local-level legislation obviously varies among countries. Many nation states have taken on greater roles over time, and particularly after World War II, in policy areas such as social welfare legislation, education, and large-scale infrastructure investments (e.g., Lindert 2004), leaving less room for local policy initiatives. Yet, the comprehensiveness (and effectiveness) of national legislative initiatives still varies considerably across regions. We expect that that local-level institutions are particularly

\footnotetext{
${ }^{3}$ Yet, the centripetal forces of national government are presumably stronger - and hence more difficult for locally elected officials to counter - where national leaders are very powerful and less concerned about the preferences of local electorates. As we hypothesize below, the presence of local democracy may therefore be less effective in ensuring true political decentralization in (national-level) autocracies.

${ }^{4}$ The influence of local governance on investment is shown, e.g., by Knutsen et al. (2016), who find that mining companies in sub-Saharan Africa prefer to locate in communities where corruption is (initially) low, and that mining subsequently increases local economic growth, at least in the medium term.
} 
important for growth in times and places - e.g., Europe and North America prior to the twentieth century (Somanathan 2001) or in present-day sub-Saharan Africa (Bierschenk and Olivier de Sardan 1997) - where the national government is less engaged in the provision of public goods, thus leaving more room for local policy initiatives.

(3) The above discussion suggests that policies that can be - and often are - selected at the local level matter for economic development. Nonetheless, even if local policy-makers are able to choose the most appropriate education reform or investment policy for their municipality, there is no guarantee that they will want to pursue it. Placing power in the hands of local officials is not productive unless these officials are properly incentivized to pursue growth-enhancing policies. What is more, the various benefits claimed for decentralization, e.g., by the theory of fiscal federalism (Oates 1972), depend upon assumptions that are only plausible if some degree of local-level accountability is in place. For example, a key premise of fiscal federalism is that wherever a population is characterized by heterogeneity, overall utility is maximized when lowerlevel governments enjoy autonomy to set policies in accordance with local preferences. This seems plausible insofar as lower-level governments are responsive to local preferences. And this, in turn, presumes a mechanism of local accountability.

We surmise that well-functioning elections with multiple candidates vying for power and free-and-fair competition are critical in this regard. Here, we rely on standard models of accountability under democratic systems (Ashworth 2012; Ferejohn 1986), which suggest that competitive elections discipline incumbent politicians - whose desire to keep their jobs is contingent on the goodwill of voters - to select policies that benefit the broader community, rather than pursue narrow rent-seeking policies or outright theft.

Such mechanisms presume that voters are well informed, because only then can they properly evaluate the performance of politicians and reward or punish them accordingly (e.g., Harding 2015)..$^{5}$ a vast literature focusing on the national level highlights how asymmetric information may undermine accountability links between leaders and voters, even in the presence of multi-party competition, a (e.g., Besley 2005). To the extent that mechanisms of accountability presume the ability of the electorate to monitor, and thereby discipline, the behavior of politicians, the principle of electoral accountability could be easier to achieve at local than at national levels, especially provided that local elections are fairly free and fair (features that

\footnotetext{
${ }^{5}$ One need not assume universal suffrage for mechanisms of accountability to work at the local level (although naturally it will affect whom they work for). There are many examples of regimes at the local level that were accountable to a minority of adult residents in that locality. The key issue, in our view, is that electors are far more numerous than the officials they select, numerous enough that they cannot be compensated indefinitely through rent-seeking. The pie must also grow in order for this sizeable electorate to prosper (though this does not preclude a degree of rent-seeking).
} 
are explicitly measured and incorporated in our index of local democracy below). There are two main reasons why accountability mechanisms may work fairly well at the local level, and perhaps better than at national levels. ${ }^{6}$

First, the smaller scale of local politics should alleviate informational and collective action problems that weaken accountability. The relative transparency of smaller communities may mitigate moral hazard problems by making the actions of local politicians easier to track than the actions of national politicians located in the capital. Further, personal knowledge of local candidates should also help mitigate adverse selection problems by making it easier for voters to discern which candidates are honest, less corrupt, or simply more effective leaders. While democratic elections at the national level can also allow for selecting "good leaders" (see Besley and Reynal-Querol 2011), the closer contact and relations between voters and politicians at the local level may further mitigate the selection of "bad" politicians due to information problems. The smaller scale of local politics could also make it easier for citizens to allay collective action problems also in between elections, enabling them to organize and put pressure on politicians to enact policies that are in the interest of the wider community. Second, neighboring municipalities provide a fairly clear reference point by which economic performance can be benchmarked. Comparing the performance of neighboring municipalities is presumably more straightforward than comparing the performance of neighboring countries, and such comparisons serve as an important cue for voters in evaluating the behavior of politicians (Powell and Whitten 1993). In support of this perspective, Khemani (2001) investigates voting behavior in national and local elections in India and finds that voters are generally more vigilant in monitoring local governments.

Taken together, our argument suggests that local democracy facilitates local accountability, incentivizing politicians to provide public goods such as well-functioning infrastructure, high-quality education, and regulatory policies that attract investment. We recognize that free and fair elections are not sufficient to assure that accountability mechanisms are in place. Democratic institutions may be subverted by local capture (Bardhan and Mookherjee 2000), which may, in turn, be facilitated by, for instance, high economic inequality (Ziblatt 2008). Nor does the absence of local democracy preclude the provision of public goods (Tsai 2007). However, as a general rule we expect that accountability, and thus, e.g., the

\footnotetext{
${ }^{6}$ This does not necessarily mean that accountability always decreases in the size of the political unit. There may be countervailing mechanisms contributing to higher accountability in modestly sized (e.g., large municipalities) than in very small units. For instance, Gerring et al. (2015) show that districts with larger electorates "mechanically" induce greater multi-party/candidate contestation, which may enhance accountability.
} 
provision of public goods, varies with the robustness of local democracy (Blair 2000; Crook and Manor 1998; Echeverri-Gent 1993).

Our theoretical discussion suggests one principal implication - that local democracy should foster improved economic performance - and two subsidiary hypotheses about contexts that might favor this relationship. First, local democracy should have greater impact on growth in contexts where local governments have considerable autonomy (vis-à-vis the national government). We surmise, therefore, that under national regimes where the leader's powers are constrained and where multiparty competition is accepted and shapes the incentives of leaders, local democracy will have a stronger growth effect. Second, local democracy should have greater impact on growth in contexts where it enjoys a preeminent policy-making role (vis-à-vis the national government), i.e., prior to World War II in advanced industrial countries (Somanathan 2001) and after World War II in newly established states, e.g. in Sub-Saharan Africa, where the presence of the central state is often weak especially in the provinces (Bierschenk and Olivier de Sardan 1997).

\section{Research Design}

In the introduction we reviewed national-level studies of (national) democracy and decentralization, noting that empirical results are inconclusive. Also germane to our topic are studies where regions or cities serve as units of analysis. In particular, several historical studies show that local areas with autonomy or limited government in the pre-modern era enjoy higher social capital, better governance, and/or stronger economic performance in subsequent centuries (Bosker, Buringh, and van Zanden 2013; Giuliano and Nunn 2013; Guiso, Sapienza, and Zingales 2008; Jacob 2010; but, see Abramson and Boix 2014). This offers some grist for our theory, even though it pertains to a very different historical era and utilizes concepts and measures that fit loosely upon the theory sketched in Section I.

Local-level studies on the contemporary era are generally more limited in scope, focusing on a single country or a small handful of countries (e.g., Crook and Manor 1998; Levy 1999; Oxhorn, Tulchin and Selee 2004). One study of the introduction of local democracy in China suggests that local areas with elective governments enjoy stronger institutions and more public goods (Martinez-Bravo, Padró i Miquel, Qian, and Yao 2014). A study of local governments in Brazil finds significantly less corruption in municipalities where mayors are eligible for reelection (Ferraz and Finan 2011). However, Gèlineau and Remmer (2006) find mixed results regarding decentralization and the match between citizen preferences and the allocation of public 
resources in Argentina. Likewise, Moricz and Sjöholm (2014) examine the effect of the staggered introduction of local elections in Indonesia and find no effect on subsequent economic growth across districts.

Our theoretical interest is at the polity level. Specifically, we ask whether local-level democracy enhances national economic growth. This is not a question that can be answered definitively with subnational data. First, the scope for within-country analysis is, in practice, limited. In the modern era, most countries introduce local democracy in a uniform manner (across all districts at once), leaving little opportunity for analyses that are disaggregated at the subnational level. China and Indonesia are unusual in this regard, and it is questionable whether one may generalize from their experience to the experience of other countries. Indeed, our argument provides strong reasons to suppose that the aggregate impact of local democracy on growth depends upon contextual factors that are not apparent when countries are evaluated in isolation. Second, direct measures of municipal-level economic growth - our dependent variable of interest - are hard to come by. And, even for the few countries that do have municipal-level estimates of growth, such as Brazil, time-series are very short.

A third problem with subnational analysis of this question involves interference across local-level units. Consider that municipalities with greater autonomy and/or democracy may prosper by attracting physical capital and human capital from surrounding areas that are less autonomous and/or less democratic. If so, the impact of local institutions is primarily redistributive - shifting growth from one area to another - rather than aggregative. Alternatively, if there are strong and positive economic spill-over effects via trade or increased demand from citizens in neighboring municipalities, improvements in local democracy in one municipality may generate growth benefits in a wider geographic area. In other words, one cannot assume that municipality-level relationships aggregate up to national levels because of violations of the stable unit treatment value assumption.

For these reasons, it is vital to complement existing subnational studies with a comprehensive national-level analysis of the relationship between local democracy and economic performance. To our knowledge, no such analysis has ever been conducted, although there is some cross-national evidence of a connection between local democracy and public goods provision, proxied by educational attainment. ${ }^{7}$ The major innovation of the present study is to

\footnotetext{
${ }^{7}$ In a recent working paper, Ponce-Rodrigues et al. (2016) argue that the combination of elective subnational governments and party centralization (i.e., the power of national party leaders to nominate candidates for subnational office) leads to enhanced educational attainment. This is tested in a panel analysis of 125 countries across twenty-five years. We replicate this result in Appendix A using our novel measure of local democracy and measures of average years of schooling from Barro and Lee (2013), supporting the notion that local democracy enhances education.
} 
measure local democracy in a consistent fashion across countries and over time, enabling the first systematic cross-national test of local democracy as a factor in economic growth.

\section{A Local Democracy Index}

To operationalize the concept of local democracy we draw on three variables from the recently completed Varieties of Democracy (V-Dem) dataset (Coppedge et al. 2016). These variables measure whether local governments are elected (v2ellocelc), whether sub-national elections are generally free and fair (v2elffelr), and the power of elected local offices relative to non-elected local offices $(v 2$ ellocpwr). All three indicators are re-scaled from 0-1 and then multiplied together to form a Local Democracy Index (LDI). ${ }^{8}$

The intuition behind this multiplicative aggregation scheme is that complementarities exist across the three components (see Munck 2009). Specifically, in order for local democracy to be fully established three conditions must be satisfied: there must be local elections, these elections must be free and fair, and officials selected in these elections must be preeminent relative to other (unelected) local-level officials. If any of these conditions fails entirely (signified by a zero score on at least one component variable), the concept of local democracy is fatally undermined. For example, local multi-party elections do not matter if the elected officials have no power and say, whatsoever, over policy decisions. If all conditions are satisfied to some extent (possessing non-zero values) then the quality of local democracy is regarded as having a positive (non-zero) value.

Figure 1 illustrates the evolution in LDI globally from 1900 to 2012, displaying mean as well as 5, 25, 75, and 95 percentile scores for each year. As suggested by the modest change in 95 percentile scores, from about .50 in 1900 to about 65 in 2012, countries with high levels of local democracy have existed throughout the period. Nonetheless, the sharper increase in 75 percentile scores, from about .15 in 1900 to about .45 in 2012, signifies that more countries have at least decent levels of local democracy today than a century ago. Increases in the 75 percentile and mean LDI scores were particularly pronounced right after World War II and from the 1980s to the mid-2000s (after which there has been stagnation). These statistics also suggest that local democracy was in decline in the 1930s and early 1940s.

\footnotetext{
${ }^{8}$ For methodological considerations pertaining to V-Dem data in general, see Pemstein et al. (2015). McMann, who was responsible for creating the indicators, provide a more specific discussion of the indicators entering LDI, including a careful evaluation of their reliability and validity (McMann 2016). McMann (2016) also sets forth the VDem index of local democracy. This index combines (a) whether local government is elected (v2ellocelc) and (b) the power of elected local offices relative to non-elected local offices ( $v 2$ ellocpwr) - but does not incorporate whether sub-national elections are generally free and fair (v2elffelr). McMann's index and our own are highly correlated $(\mathrm{r}=.956)$ and generate fairly similar results when tested in our benchmark model, as displayed in Table 3.
} 
Figure 2 displays histograms over LDI for different regions in the year 2000 (histograms for 1900 and 1950 are shown in Appendix A). Most regions display substantial cross-country variation. In Eastern Europe and the post-Soviet space, seven countries scored below .05 on LDI and seven others above .45. The variation was also quite substantial in Latin America and in Asia and the Pacific. In the composite Western "region" scores were generally high, as only Cyprus and Israel score below .50, and only Turkey and Iran scored higher than .10 among the MENA countries.

Figure 1: Average LDI and variation in LDI, globally, over time.

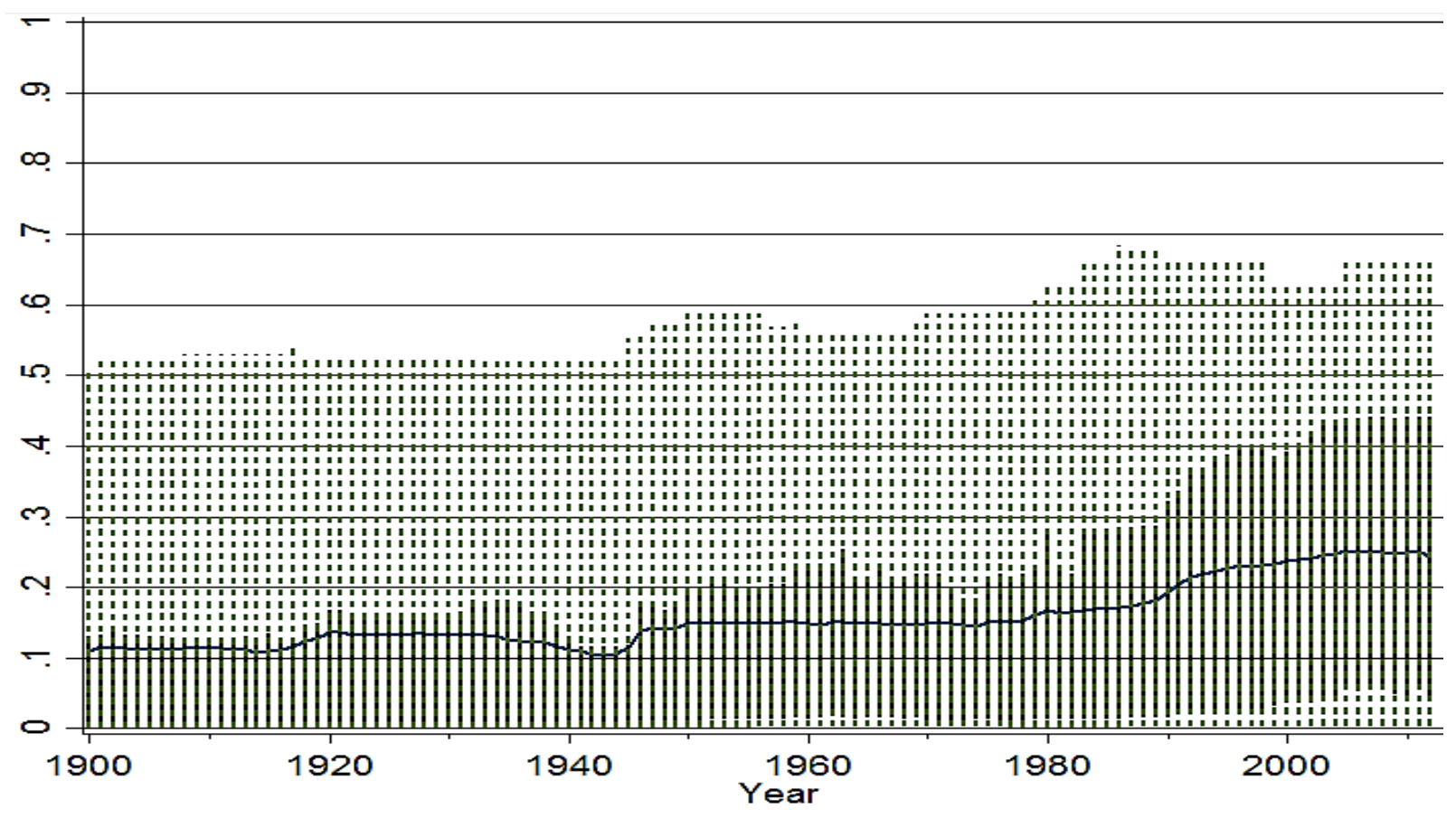

Notes: Solid line represents mean LDI score globally, solid spikes range from 25 percentile to 75 percentile observation in given year, and dashed spikes range from 5 percentile to 95 percentile observation in given year. 
Figure 2: Histograms of LDI by major world regions

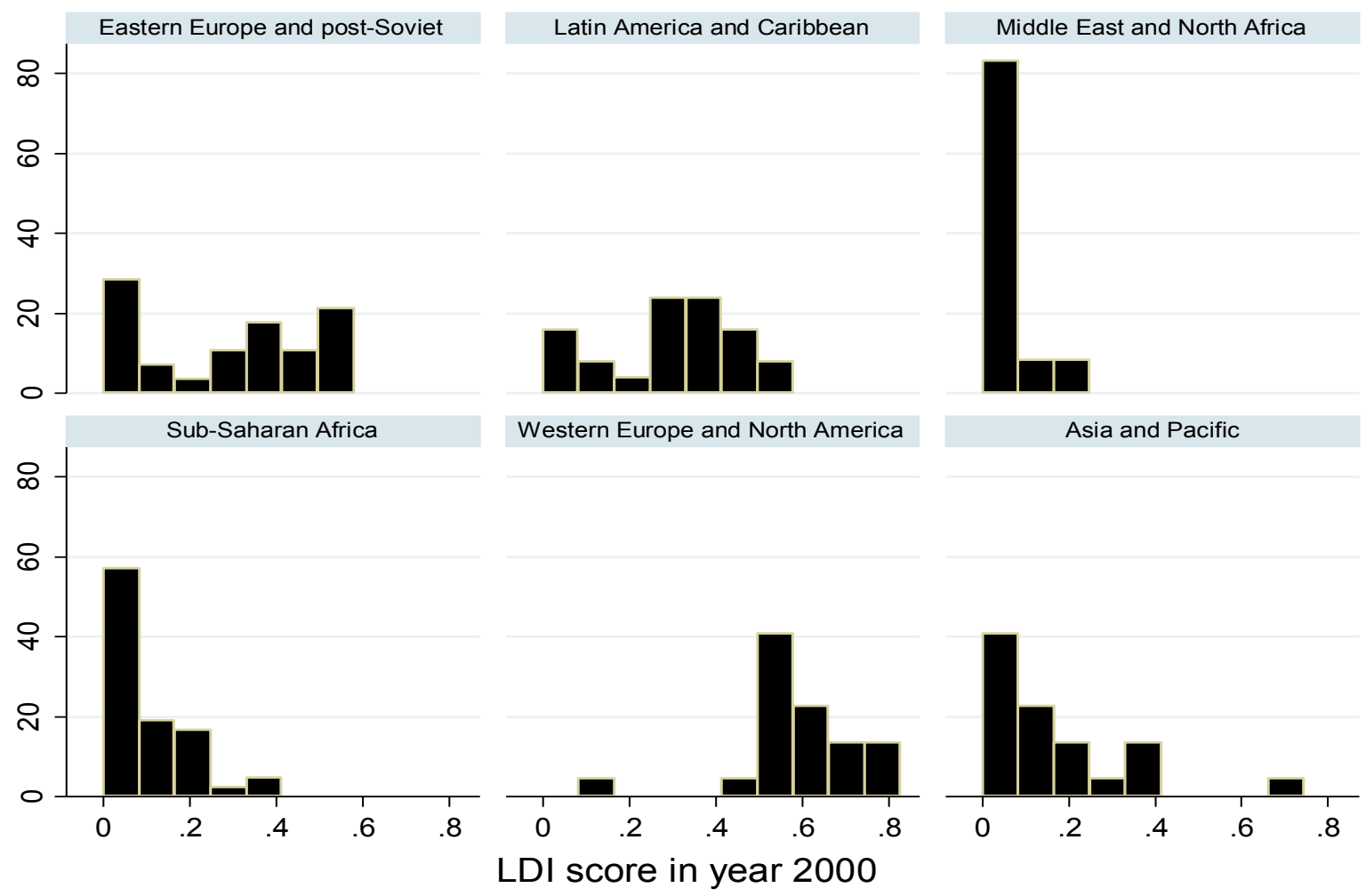

\section{Benchmark specification}

To test the relationship between local democracy and growth we adopt a panel format that extends across all sizeable sovereign countries from 1900 to the present. The baseline sample includes roughly 10,000 country-year observations from about 150 countries. The dependent variable is the annual growth of real PPP-adjusted GDP per capita, drawn from the Maddison Project (Bolt and van Zanden 2014).

The benchmark specification includes (log) GDP per capita level (also from Bolt and van Zanden 2014) to account for conditional convergence effects (Barro and Sala-i-Martin 2004). This specification also includes country dummies - a fixed-effects framework - in order to control for stable, unit-specific features that may serve as confounders. We also include year dummies to control for global temporal patterns in growth and local democracy.

The benchmark model adopts an ordinary least squares (OLS) estimator with robust standard errors clustered by country in order to handle serial autocorrelation. Right-side variables 
are lagged three periods (i.e., three years) behind the outcome. This follows Papaioannou and Siourounis (2008), who suggest that democratization is often associated with short-term turmoil and uncertainty, culminating in a new equilibrium about three years later. Likewise, the pathway we have conjectured - through electoral accountability and the implementation of growthenhancing policies - presumably requires some time to reach fruition. Since precise expectations about the length of the lag are impossible to infer on theoretical grounds, we explore alternate lag specifications in additional tests.

The resulting baseline model is fairly sparse so as to mitigate risks of post-treatment bias. Robustness tests incorporate a larger set of covariates, such as population size, urbanization, civil war, natural resources and land inequality, in order to mitigate risks of omitted-variable bias but with the risk of introducing post-treatment bias.

\section{Initial Tests}

Model 1 in Table 1, the benchmark model, reveals a coefficient for LDI that is statistically significant at the 5 percent level. The point estimate suggests that an improvement in local democracy from the lowest $(0)$ to the highest value registered in our sample (0.83; Germany in the most recent years) would enhance a country's per capita growth rate by 1.7 percentage points. Accordingly, differences in local democracy are predicted to give substantial differences in level of development over time. If two countries begin with identical per capita incomes but maintain divergent LDI scores (at either extreme), the country with high LDI will become twice as wealthy after about 40 years.

We return to further tests of this relationship in the next section. But first - in order to put these results into perspective and to replicate extant work on decentralization and democracy, reviewed at the outset - we present a series of tests focused on the latter concepts.

To operationalize decentralization, we first adopt a common fiscal measure of that concept: the share of general revenue raised at subnational levels, compiled by Enikolopov and Zhuravskaya (2007). As our introductory review noted, there are empirical indications that fiscal decentralization correlates with growth. Yet, the limited cross-country coverage and modest time series of available measures means that it is difficult to identify effects in more demanding designs that account for country- and year-fixed effects. This is illustrated also by our benchmark specification, Model 2 in Table 1. With 98 countries (a number that is markedly higher than in extant studies) and a maximum of 29 years, the positive coefficient on fiscal decentralization fails to achieve significance at conventional levels with a t-value of 1.6. 
Granted, our benchmark specification provides a fairly strict test by controlling for both country- and year-fixed effects, and less demanding specifications may yield somewhat stronger indications of a relationship. This point is illustrated by Model 3, in which the year dummies are replaced by a cubic polynomial time trend (following Carter and Signorino 2010). Here, we find a similarly sized coefficient (0.04) that is weakly significant at 10 percent. Model 4 employs a different measure of decentralization, focused on formal-political arrangements, i.e., federalism. Gerring and Thacker (2008) measure countries as non-federal (0), semi-federal (1), or federal (2). ${ }^{9}$ While Model 4 includes 129 countries and maximum timespan of 103 years, the association between federalism and growth does not surpass conventional statistical thresholds of significance (and this result is actually weakened when we use a cubic time trend instead of year dummies). These tests suggest that the empirical relationship between decentralization and growth is weak, at best.

${ }^{9}$ While this measure is ordinal, we retain our benchmark OLS model to ease comparisons across measures. 
Table 1: Initial Tests

\begin{tabular}{|c|c|c|c|c|c|c|c|c|c|c|c|}
\hline & \multirow{2}{*}{$\begin{array}{l}\text { Local democracy } \\
1\end{array}$} & \multicolumn{3}{|c|}{ Decentralization } & \multicolumn{4}{|c|}{ National democracy } & \multicolumn{3}{|c|}{ Horse-race tests } \\
\hline & & 2 & 3 & 4 & 5 & 6 & 7 & 8 & 9 & 10 & 11 \\
\hline LDI & $\begin{array}{l}2.06^{* *} \\
2.09\end{array}$ & & & & & & & & $\begin{array}{l}1.85^{*} \\
1.88\end{array}$ & $\begin{array}{l}3.44^{* * *} \\
3.25\end{array}$ & $\begin{array}{l}2.54^{*} \\
1.96\end{array}$ \\
\hline Fiscal decentralization & & $\begin{array}{l}0.04 \\
1.58\end{array}$ & $\begin{array}{l}0.04^{*} \\
1.68\end{array}$ & & & & & & & & \\
\hline Federalism & & & & $\begin{array}{l}0.37 \\
1.35\end{array}$ & & & & & $\begin{array}{l}0.35 \\
1.23\end{array}$ & & $\begin{array}{l}0.47^{*} \\
1.80\end{array}$ \\
\hline Polyarchy & & & & & $\begin{array}{l}0.32 \\
0.39\end{array}$ & $\begin{array}{l}1.48^{*} \\
1.87\end{array}$ & & & & $\begin{array}{l}-1.98^{* *} \\
-2.22\end{array}$ & $\begin{array}{l}-1.70^{*} \\
-1.77\end{array}$ \\
\hline Polity2 & & & & & & & $\begin{array}{l}-0.01 \\
-0.24\end{array}$ & & & & \\
\hline BMR & & & & & & & & $\begin{array}{l}-0.14 \\
-0.54\end{array}$ & & & \\
\hline Ln GDP per capita & $\begin{array}{l}-2.84 * * * \\
-6.61\end{array}$ & $\begin{array}{l}-6.95^{* * *} \\
-4.46\end{array}$ & $\begin{array}{l}-7.34 * * * \\
-4.84\end{array}$ & $\begin{array}{l}-3.95^{* * *} \\
-6.31\end{array}$ & $\begin{array}{l}-2.54 * * * \\
-6.78\end{array}$ & $\begin{array}{l}-2.86^{* * *} \\
-7.39\end{array}$ & $\begin{array}{l}-2.84^{* * *} \\
-7.19\end{array}$ & $\begin{array}{l}-2.94 * * * \\
-7.39\end{array}$ & $\begin{array}{l}-3.97 * * * \\
-6.29\end{array}$ & $\begin{array}{l}-2.81 * * * \\
-6.32\end{array}$ & $\begin{array}{l}-4.14 * * * \\
-6.23\end{array}$ \\
\hline Country dummies & $\mathrm{Y}$ & $\mathrm{Y}$ & $\mathrm{Y}$ & $\mathrm{Y}$ & $\mathrm{Y}$ & $\mathrm{Y}$ & $\mathrm{Y}$ & Y & $\mathrm{Y}$ & Y & $\mathrm{Y}$ \\
\hline Year dummies & $\mathrm{Y}$ & $\mathrm{Y}$ & & $\mathrm{Y}$ & $\mathrm{Y}$ & & $\mathrm{Y}$ & $\mathrm{Y}$ & $\mathrm{Y}$ & $\mathrm{Y}$ & $\mathrm{Y}$ \\
\hline Cubic time trend & & & Y & & & Y & & & & & \\
\hline$N$ & 9231 & 1316 & 1316 & 4840 & 9693 & 9693 & 10354 & 10181 & 4693 & 8950 & 4587 \\
\hline Countries & 149 & 98 & 98 & 129 & 152 & 152 & 155 & 153 & 125 & 149 & 125 \\
\hline Max years & 108 & 29 & 29 & 103 & 108 & 108 & 208 & 107 & 103 & 108 & 103 \\
\hline$R^{2}$ & 0.11 & 0.10 & 0.06 & 0.14 & 0.11 & 0.02 & 0.11 & 0.11 & 0.14 & 0.11 & 0.15 \\
\hline
\end{tabular}

Notes: $* \mathrm{p}<0.1,{ }^{* *} \mathrm{p}<0.05,{ }^{* * *} \mathrm{p}<0.01$. T-stats are reported directly below regression coefficients in italics. All models are (fixed effects) OLS models with robust errors clustered by country. GDP per capita growth is the dependent variable in all models. Independent variables are measured three years before dependent variable. Country dummies, year dummies, cubic time polynomials and constant are omitted. 
We turn now to the relationship between national-level democracy and growth. To measure democracy we employ the Polyarchy index from V-Dem (Teorell et al. 2016), the Polity2 index from Polity IV (Marshall et al. 2014), and the dichotomous "BMR" measure from Boix, Miller and Rosato (2013). Model 5, our benchmark model, uses Polyarchy, which ranges from $0-1$ and includes indicators on whether or not the chief executive is (directly or indirectly) elected, the extent to which national elections are "clean", the freedoms of association and speech, and suffrage extension. Hence, Polyarchy is an electoral democracy measure (as is our LDI measure of local democracy) that mainly caters to the conditions for elite competition through multi-party elections at the national level. Polyarchy is positive, but far from significant at conventional levels, suggesting no clear effect of national-level democracy on growth. When year dummies are replaced with a cubic time trend, as shown in Model 6, the relationship becomes weakly significant.

This reflects the more general pattern that we find when we test various model specifications and measures of democracy at the national level. Some models suggest a positive relationship between democracy and growth, but this hinges on specification choices. More specifically, models including country- and year-fixed effects simultaneously do not yield any clear results. This is illustrated in Models 7 and 8 , which are versions of our baseline model where Polyarchy is replaced by, respectively, Polity2 (which in addition to electoral aspects includes checks placed on the chief executive) and BMR (a dichotomous, electoral democracy measure). In sum, we replicate the findings of most extant studies (cited at the outset), which show no robust association between democracy at the national level and economic growth.

The final section of Table 1 displays "horse-race" regression tests, in which LDI and measures of decentralization (federalism) and/or democracy (Polyarchy) are included together in the benchmark model, allowing us to distinguish the impact of various institutional features. (We do not focus on fiscal decentralization here because of the poorer data coverage.) In particular, we need to ensure that the positive estimate for LDI is not simply a product of omitted variable bias stemming from differences in national-level democracy or decentralization. This seems not to be the case, as LDI retains its size and remains at least weakly significant in all specifications. ${ }^{10}$ Regarding the relationship between national-level democracy and growth, Polyarchy actually turns negative and significant at 5 percent when we account for level of local democracy in

10 This holds also more generally when LDI is combined with the other measures of democracy (Appendix Table B.2). It does not hold when LDI is combined with the fiscal decentralization measure, restricting the sample to only 1260 country-year observations from the most recent decades. As theorized, and shown empirically below, the relationship between LDI and growth is weaker in recent decades than previously. 
Model $10 .{ }^{11}$ We also note that the federalism index turns weakly significant in the three-way horse race in Model 11. ${ }^{12}$

The inclusion of another V-Dem measure than LDI (Polyarchy) in the rightmost columns of Table 1 also addresses a concern that coders for the V-Dem project may unwittingly judge a country's institutions by its economic performance - granting higher scores to countries with higher growth rates, and thus generating circularity between left- and right-side measures. If this sort of coding bias were in evidence, we would expect it to manifest itself for other V-Dem measures. (We also included other V-Dem indices such as party institutionalization and executive corruption in horse-race tests, with no change in the findings reported here.). Indeed, we might expect a country's growth rate to have greater impact on coding for national institutions than for local institutions, and Models 5-6 reveal scant evidence of coding circularity with respect to democratic institutions at the national level. And when Polyarchy is included along with LDI in the horse-race test of Model 10, the estimate for LDI is even stronger than in our benchmark model. In sum, initial tests suggest a positive relationship between local democracy and subsequent economic growth, and little evidence for a direct growth effect from conventional measures of decentralization and national-level democracy.

\section{Robustness Tests}

To probe the robustness of the relationship between LDI and growth we test several additional models, as shown in Table 2 (see also Appendix B). Model 1 replicates the benchmark specification from Table 1. Model 2 adopts the alternative strategy for modeling time-dependence using cubic polynomial time trends rather than annual dummies. After doing so, the point estimate increases by 60 percent relative to the benchmark (to 3.3), and the t-value by 50 percent (to 3.1).

Model 3 adjusts on the baseline by including a lagged dependent variable (growth measured three years prior) to control for persistence in growth rates affecting results. The results barely move relative to the benchmark, and LDI remains significant at 5 percent. We

\footnotetext{
11 This result is not robust to small specification changes, as Polyarchy is insignificant at all conventional levels when, e.g., year dummies are substituted with cubic time polynomials or when controls such as log population and urbanization are added. Hence, we caution against interpreting this finding as evidence of a negative direct effect of national-level democracy on growth. Still, Polyarchy consistently drops in absolute size whenever we add LDI to the regression, suggesting a possible (positive) indirect effect of national-level democracy on growth via local democracy. As we discuss in the concluding section, this hinges on the assumption that national-level democracy determines local democracy, and not the other way around, and we leave further investigation of this intriguing relationship for future research.

12 Unlike the local democracy result, this finding is sensitive to minor specification changes, such as substituting year dummies with the cubic time trend.
} 
tested models including several additional lags, both backwards in time as well as growth measured between $\mathrm{t}-3$ and $\mathrm{t}$, and the result is very stable (Appendix Table B.3). To investigate whether persistence in LDI drives the results, Model 4 substitutes LDI with change in LDI from $\mathrm{t}-3$ to $\mathrm{t}-2$ and predicts that improvements in local democracy are clearly linked $(\mathrm{t}=2.6)$ to higher subsequent growth.

Our baseline model is quite sparse, and one might be concerned that the relationship is driven by omitted variable bias despite the inclusion of country- and year-fixed effects. Model 5, Table 2 therefore adds controls for (log) population level and urbanization rate to account for two plausible sources of omitted variable bias. The size (and growth) of the population has been highlighted by different growth economists as an important determinant of growth, albeit with different directions on the predicted effect (cf., Solow 1956; Romer 1990), and local democracy is also correlated with the size of the country. ${ }^{13}$ Further, urban economies are associated with a different sectoral composition than agrarian, and may allow for increased growth through "agglomeration effects" (e.g., Krugman 1991). Urbanized countries also tend to score higher on LDI, according to our data. Nonetheless, controlling for urbanization and population size in Model 5 only reduces LDI from 2.1 to 1.8 , and it remains significant at 10 percent.

Model 6 expands on Model 5 by adding three more variables that capture different factors that may affect growth and correlate with LDI, namely conflict, natural resources and inequality (see also Appendix Table B.4). More specifically, Model 6 includes fuel income per capita (scaled to per 1000 capita) and a dummy for civil war, both taken from Haber and Menaldo (2011). It finally includes the Family Farms measure from Vanhanen (2000) to account for differences in agricultural production and inequality. LDI increases to 2.8 when these controls are added and obtains a t-value of $2.3 .^{14}$

\footnotetext{
${ }^{13}$ Nonetheless, Przeworski et al. (2000) argue and find that regime type affects population growth rates, and controlling for population variables might thus introduce post-treatment bias.

${ }^{14}$ Further tests reveal that the increase in LDI coefficient relative to the benchmark is due to the reduced sample size (6194 obs. instead of 9231), which comes from missing values on the control variables.
} 
Table 2: Robustness Tests

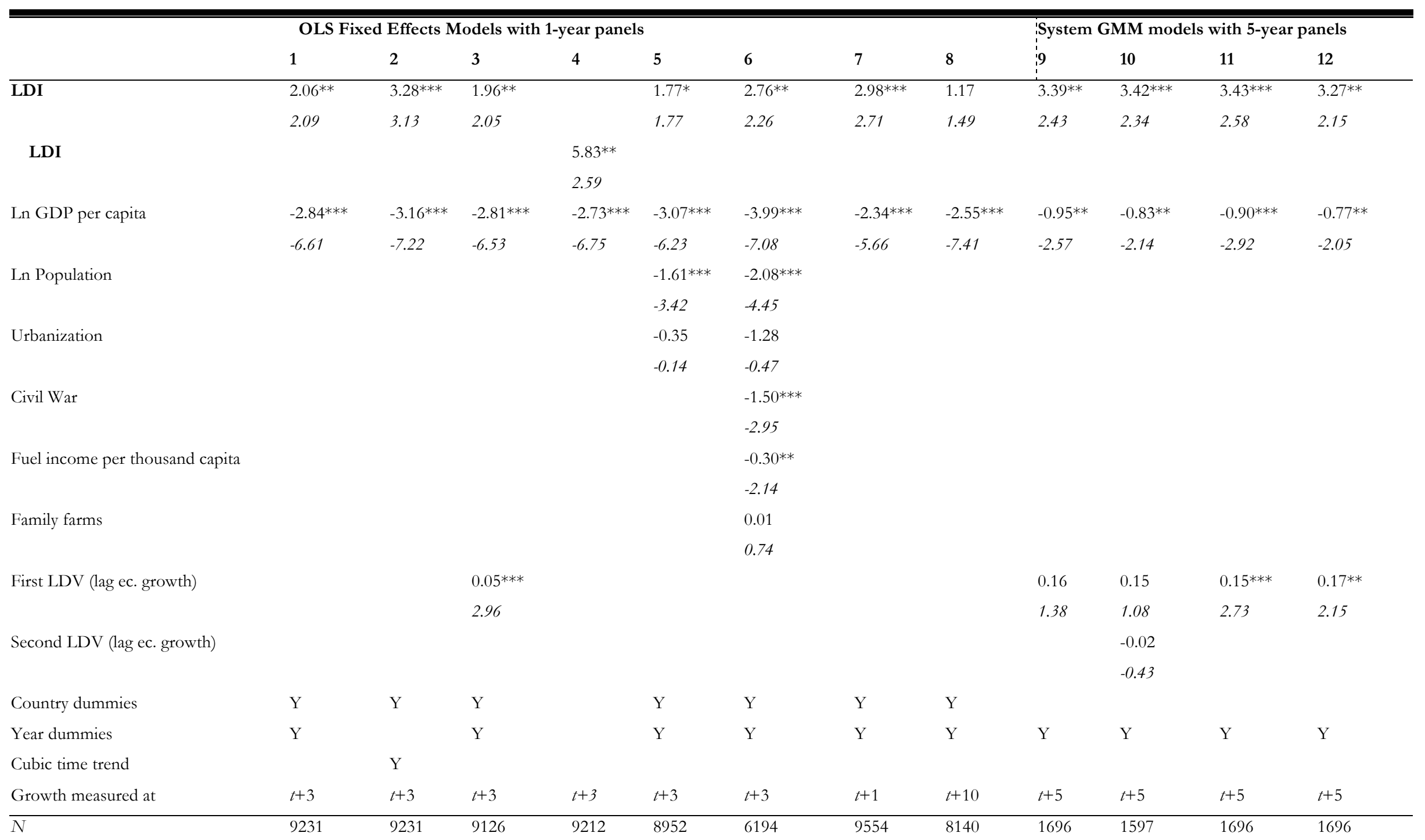




\begin{tabular}{|c|c|c|c|c|c|c|c|c|c|c|c|c|}
\hline Countries & 149 & 149 & 149 & 149 & 144 & 138 & 149 & 149 & 149 & 149 & 149 & 149 \\
\hline Max years/5-year panels & 108 & 108 & 108 & 108 & 108 & 99 & 110 & 101 & 21 & 21 & 21 & 21 \\
\hline$R^{2}$ & 0.11 & 0.03 & 0.11 & 0.11 & 0.12 & 0.12 & 0.11 & 0.11 & & & & \\
\hline$A R(2)$ test & & & & & & & & & .30 & .37 & .15 & .15 \\
\hline $\operatorname{Ar}(3)$ test & & & & & & & & & .39 & .38 & .39 & .39 \\
\hline Hansen J-test & & & & & & & & & .17 & .20 & .91 & .61 \\
\hline Treated as endogenous & & & & & & & & & LDI & LDI & $\mathrm{LDI}+\mathrm{LDV}$ & $\mathrm{LDI}+\mathrm{LDV}$ \\
\hline Lags used for instruments & & & & & & & & & $2-4$ & $2-4$ & $2-4$ & $3-4$ \\
\hline Instruments (N) & & & & & & & & & 94 & 94 & 175 & 135 \\
\hline
\end{tabular}

Notes: ${ }^{*} \mathrm{p}<0.1,{ }^{* *} \mathrm{p}<0.05,{ }^{* * *} \mathrm{p}<0.01$. T-stats are reported directly below regression coefficients in italics. GDP per capita growth is the dependent variable in all models. All OLS models are

estimated with robust errors clustered by country, and all GMM models with robust errors. All variables are calculated as moving averages in the 5-year panels. Country dummies, year dummies and constant are omitted. 
In Models 7 and 8, we experiment with different lag lengths than our baseline 3-year lag. Results are fairly stable as long as the lag length does not exceed 10 years (see also Appendix Table B.5). Model 7 shows that LDI is highly significant for a shorter (1-year) lag than the baseline specification. Model 8 illustrates that the relationship weakens when the lag length increases substantially (to 10 years), although the coefficient is still fairly sizeable (1.2) and the tvalue is 1.5 . These tests suggest that the relationship between local democracy and growth is fairly proximal. One plausible reason for this is suggested by our argument on local democracyinducing policies - including in the realm of education, healthcare, and business regulation - that should largely affect human capital and physical capital. These features are by many growth economists argued to only affect medium-term growth (e.g., Mankiw et al. 1992), in contrast with technological change, which affects also long-term growth.

Nonetheless, when growth is measured before local democracy, there is no positive relationship whatsoever. To exemplify, when growth is measured in t-1 in the baseline (with local democracy measured in $\mathrm{t}$ ) the LDI coefficient is negatively signed (though insignificant at all conventional levels). Further, Granger-type causality tests (see Appendix Table B.6) - predicting LDI with lagged growth, controlling for lagged LDI- actually suggest that higher growth predicts lower scores on LDI. These tests partly assuage concerns that the positive LDI coefficient in our baseline model is driven by growth causing higher levels of local democracy.

However, utilizing the time dimension and conducting Granger tests is not a bulletproof strategy for dealing with potential endogeneity biases, and nor is including a control for the level of income as well as country- and year-fixed effects (though they surely help). Unfortunately, identifying valid instruments for local democracy that are both strong and satisfy the exclusion restriction is difficult.

As a next-best expedient, we employ Generalized Method of Moments (GMM) that treat LDI as an endogenous regressor. More specifically, we opt for System GMM models that include both levels and differences equations, and employ lags in levels as instruments for differences and lags in differences as instruments for levels. ${ }^{15}$ When doing so, we follow standard practice and employ longer 5-year panels (taking moving averages for all variables). This is necessary for GMM models when time series are as extensive as ours, since only then can we avoid the problem of having too many instruments (Roodman 2009). Including too many instruments reduces the trustworthiness of the GMM estimates and the accompanying

\footnotetext{
${ }^{15}$ We follow standard practice and report System GMM rather than Difference GMM ("Arellano-Bond") given the sluggish nature of LDI (see Blundell and Bond 1998 for simulations on the relative performance of System and Difference GMM models under different conditions).
} 
specification tests. As a rule-of-thumb, the number of instruments should be lower than the number of cross-section units.

In Model 9 we include only the first lag of the dependent variable as a regressor, and only LDI is treated as endogenous. (When multiple variables are treated as endogenous, we again quickly run into the problem of too many instruments, but see Models 11 and 12). Model 9 uses the second to fourth lags for instruments, and the instrument count (94) is well below the number of cross-section units (149). LDI remains significant at 5 percent, and the point estimate is 3.4. This suggests that the short-term effect of going from the minimum (0) to maximum observed (.83) score on LDI is about 2.8 percentage points higher GDP per capita growth. The estimated long-term effect (calculated as LDI / 1 - LDV) is only slightly higher, at 3.3 percentage points. The $\operatorname{AR}(2)$ test $(\mathrm{p}=.30)$ and Hansen J-test $(\mathrm{p}=.17) \mathrm{p}$-values are sufficiently high to suggest that Model 9 could yield a consistent estimate of the causal effect of local democracy on growth.

As indicated by Models 10-12, this result is fairly robust to altering the GMM specification. In Model 10, a second lag of the dependent variable is added to Model 9, and the results and specification tests are basically unaltered. Model 11 alters Model 9 by also treating the lagged dependent variable as endogenous. This strengthens the LDI coefficient both in terms of size and significance $(\mathrm{t}=2.6)$, and further improves the Hansen J-test on the overidentification restrictions $(p=.91)$. However, we note that the number of instruments exceeds the number of cross-section units in this specification. To alleviate this latter concern, we run Model 12, which now only uses the third and fourth lags for instrumentation, and the LDI coefficient remains stable and significant at 5 percent.

In sum, the GMM results give us further reason to believe that we are actually tapping into a positive effect of local democracy on growth. We note that the usual caveats related to drawing strong causal inferences from national-level observational data apply, but to the extent that this is possible our tests corroborate the main hypothesis.

\section{Alternate Measures of Subnational Democracy}

Tests presented in Table 3 investigate whether omitting single indicators from our Local Democracy Index affects the result. To recap, LDI incorporates three indicators, capturing a) whether local officials are elected, b) the extent to which sub-national elections are free and fair, and c) the relative power of elected local officials vs. non-elected local officials. These indicators are multiplied, meaning that high levels of local democracy can only be ensured when there are 
local elections, these elections allow for free and fair competition and the elected local officials are powerful relative to non-elected officials.

Table 3: Alternate measures

\begin{tabular}{|c|c|c|c|c|c|c|}
\hline & \multirow{2}{*}{$\begin{array}{l}\text { Baseline } \\
1\end{array}$} & \multicolumn{2}{|c|}{ LDI disaggregated } & \multicolumn{2}{|c|}{ Alternate indices } & \multirow[b]{2}{*}{6} \\
\hline & & 2 & 3 & 4 & 5 & \\
\hline \multirow[t]{2}{*}{ LDI } & $2.06^{* *}$ & & & & & $2.51 * *$ \\
\hline & 2.09 & & & & & 2.34 \\
\hline \multirow[t]{2}{*}{ LDI w.o. free and fair elections } & & $1.56^{*}$ & & & & \\
\hline & & 1.93 & & & & \\
\hline \multirow[t]{2}{*}{ LDI w.o. relative power of elected offices } & & & $1.48^{*}$ & & & \\
\hline & & & 1.84 & & & \\
\hline \multirow[t]{2}{*}{ Subnational democracy index } & & & & $1.87^{*}$ & & \\
\hline & & & & 1.75 & & \\
\hline \multirow[t]{2}{*}{ Regional democracy index } & & & & & 1.42 & -0.47 \\
\hline & & & & & 1.53 & -0.49 \\
\hline \multirow[t]{2}{*}{ Ln GDP per capita } & $-2.84 * * *$ & $-2.76^{* * *}$ & $-2.81 * * *$ & $-2.84 * * *$ & $-2.71 * * *$ & $-2.84 * * *$ \\
\hline & -6.61 & -6.80 & -6.67 & -6.54 & -6.68 & -6.51 \\
\hline Country dummies & Y & $\mathrm{Y}$ & $\mathrm{Y}$ & Y & $\mathrm{Y}$ & Y \\
\hline Year dummies & $\mathrm{Y}$ & $\mathrm{Y}$ & $\mathrm{Y}$ & $\mathrm{Y}$ & Y & Y \\
\hline $\bar{N}$ & 9231 & 9480 & 9190 & 9127 & 9515 & 9127 \\
\hline Countries & 149 & 149 & 149 & 148 & 150 & 148 \\
\hline Max years & 108 & 108 & 108 & 108 & 108 & 108 \\
\hline $\mathrm{R}^{2}$ & 0.11 & 0.11 & 0.11 & 0.21 & 0.11 & 0.11 \\
\hline
\end{tabular}

Notes: ${ }^{*} \mathrm{p}<0.1,{ }^{* *} \mathrm{p}<0.05,{ }^{* * *} \mathrm{p}<0.01$. T-stats are reported directly below regression coefficients in italics. All models are (fixed effects) OLS models with robust errors clustered by country. GDP per capita growth is the dependent variable in all models. Independent variables are measured three years before dependent variable. Country dummies, year dummies and constant are omitted.

While we clearly prefer this measure, one might question whether invoking evaluations of the freeness and fairness of elections introduces subjectivity bias in our measure. Others might question the relevance of including the relative power of elected officials in a measure of local democracy conceptualized in electoral terms. To ease comparisons, Model 1, Table 3 again reports the specification using the baseline LDI. Model 2, Table 3 replicates the benchmark with a reduced version of LDI omitting the free and fair elections term - this measure is equivalent to the official V-Dem Local Government Index (McMann 2016). Model 3 employs a reduced version of LDI omitting the relative power of elected officials. Results are slightly weakened when these less comprehensive measures are used in Models 2 and 3, but both models still display a weakly significant relationship with growth. In other words, our main result is not 
driven entirely by the inclusion of evaluations of freeness or fairness of subnational elections or the relative power of elected and non-elected offices at the local level. But, accounting for both these features alongside the cornerstone indicator capturing whether there are local elections gives a clearer effect on growth.

Finally, we noted how many studies in the decentralization literature have highlighted the regional (or state) level. One might expect that countries with high levels of local democracy also have high levels of "regional democracy". Since V-Dem includes similar measures of elections and relative power of elected officials for the regional level, we first constructed a more comprehensive Subnational Democracy Index (SDI), closely corresponding to LDI in structure but weighting the local and regional levels equally (see Appendix A for details). We also constructed a Regional Democracy Index (RDI) with an identical structure to LDI.

Model 4 shows that the relationship with growth is actually weakened when we substitute LDI with SDI, although SDI is significant at 10 percent. Model 5 reveals a fairly sizeable RDI coefficient, but the relationship between regional democracy and growth is statistically insignificant at conventional levels $(\mathrm{t}=1.5)$. Model 6 jointly includes LDI and RDI, and only the former coefficient is now substantial in size (2.5) and statistically significant $(t=2.3)$. Hence, our main result does not stem from democracy at the regional level (or national level, for that matter, as shown above) driving both local democracy and growth.

\section{Contextual Effects}

Our argument suggests that the relationship between local democracy and growth should be stronger in particular contexts. We thus conduct tests on restricted samples to investigate whether or not the relationship between LDI and growth operates more strongly in some geographic regions of the world, in particular periods, and in countries with (national-level) political regimes that are classified as 'democratic' according to dichotomous measure from Boix et al. (2013). These tests allow us to assess the stability of the relationship across contexts, and, perhaps more interestingly, to further probe the validity of our argument.

To recapitulate, we expect that local democracy should clearly matter for growth in contexts of national-level democracy, as the national government should be less likely to interfere with the workings of local level politics and provide more de facto autonomy for local officials to choose policies than in autocracies. Despite the literature on the workings of local elections in China and its implications for policy selection and growth, we were more skeptical that local democracy should matter in national-level autocracies, where local autonomy may 
more easily be restricted in practice. This expectation is borne out in the data, as illustrated by contrasting Model 1 (democracies) with Model 2 (autocracies). In Model 1, LDI is 3.0 and statistically significant at 5 percent; in Model 2 LDI is 1.0 with a t-value of 0.4 . This suggests that variation in local democracy matters for growth in countries that are fairly democratic at the national level, but we are not able to identify any clear effect in countries without competitive multi-party elections. ${ }^{16}$

Table 4: Split-sample tests

\begin{tabular}{lllllll}
\hline \hline Time-period & Unrestricted & Unrestricted & $\mathbf{1 9 0 0 - 1 9 6 0}$ & $\mathbf{1 9 0 0 - 1 9 6 0}$ & $\mathbf{1 9 6 0 - 2 0 1 4}$ & $\mathbf{1 9 6 0 - 2 0 1 4}$ \\
Countries & Democracies & Autocracies & Unrestricted & Western & Unrestricted Sub-Saharan Africa \\
& $\mathbf{1}$ & $\mathbf{2}$ & $\mathbf{3}$ & $\mathbf{4}$ & $\mathbf{5}$ & $\mathbf{6}$ \\
\hline LDI & $2.95^{* *}$ & 0.96 & $3.38^{*}$ & $6.39^{* *}$ & 0.16 & $9.81^{*}$ \\
& 2.15 & 0.35 & 1.79 & 2.24 & 0.14 & 1.98 \\
Ln GDP per capita & $-4.97^{* * *}$ & $-3.21^{* * *}$ & $-8.02^{* * *}$ & $-13.65^{* * *}$ & $-3.53^{* * *}$ & $-3.91^{* * *}$ \\
& -6.94 & -4.58 & -4.07 & -8.43 & -6.99 & -5.18 \\
Country dummies & $\mathrm{Y}$ & $\mathrm{Y}$ & $\mathrm{Y}$ & $\mathrm{Y}$ & $\mathrm{Y}$ & $\mathrm{Y}$ \\
Year dummies & $\mathrm{Y}$ & $\mathrm{Y}$ & $\mathrm{Y}$ & $\mathrm{Y}$ & $\mathrm{Y}$ & $\mathrm{Y}$ \\
\hline N & 3593 & 4548 & 3098 & 1138 & 6133 & 1896 \\
Countries & 101 & 121 & 113 & 21 & 149 & 42 \\
Max years & 107 & 100 & 60 & 60 & 48 & 48 \\
$\mathrm{R}^{2}$ & 0.22 & 0.12 & 0.15 & 0.23 & 0.11 & 0.10 \\
\hline \hline
\end{tabular}

Notes: ${ }^{*} \mathrm{p}<0.1,{ }^{* *} \mathrm{p}<0.05,{ }^{* * *} \mathrm{p}<0.01$. T-stats are reported directly below regression coefficients in italics. All models are (fixed effects) OLS models with robust errors clustered by country. GDP per capita growth is the dependent variable in all models. Independent variables are measured three years before dependent variable. Country dummies, year dummies, and constant are omitted.

Further, we hypothesized that local-level institutions should matter more in contexts where they, in general, have stronger leverage in terms of selecting various types of policies. This, for instance, means that we expect local democracy to make a greater difference in the early parts of the period that we study, before the development of comprehensive national-level legislation in many countries in areas such as welfare and education policies. Model 3 re-runs the baseline, but only for 1900-1959, and finds a large LDI coefficient (3.4) that is significant at 10 percent. Further tests show that this relationship, in the early part of the period, was particularly pronounced in "Western" countries (Western Europe plus Australia, Canada, New Zealand, and USA). Model 4 restricts the sample to only include Western countries for 1900-1959, and finds a

\footnotetext{
${ }^{16} \mathrm{We}$ also note that the variance of LDI is about six times larger in the former sample than in the latter. Less variation in local democracy for autocracies makes it harder to identify an effect, even if there should be one.
} 
very large LDI coefficient (6.4) that is significant at 5 percent. Going from the minimum observed (0.00) to the maximum observed (0.63) level of local democracy in this sample is predicted to increase annual GDP per capita growth by 4.0 percentage points. In contrast, there is no significant LDI coefficient on a global sample restricted to 1960 and after (see Model 5). We caution against interpreting this as clear evidence that local democracy does not relate to growth in the contemporary era. While the estimated effect is always lower in the post-1960 sample than the pre-1960 sample, plausible alternative specifications do show LDI coefficients that are statistically significant at conventional levels also for the recent period. ${ }^{17}$

However, the expectation on differences in effect over time for the global (and Western) samples was rooted in assumptions about the extent and scope of national-level policy-making and the room left for local units to select policies. This expectation should then also be applicable to contemporary contexts where the state is not the predominant unit in terms of setting policies. While there is variation between countries (Englebert 2002), Sub-Saharan Africa is often pointed out as a region where states are comparatively "weak", and where local institutions truly matter for policy-making and various outcomes (e.g., Wig 2015). When we rerun our baseline on post-1960 data for Sub-Saharan African countries (Model O), LDI is even larger (9.8) than in the pre-1960 Western sample and has a t-value of $2.0 .{ }^{18}$ Going from the minimum (0.00) to maximum observed (0.45) LDI in the African sample is predicted to increase annual growth by 4.4 percentage points. In sum, local democracy clearly enhances growth in contexts where local institutions are presumed to be relatively important compared to state-level institutions.

\footnotetext{
${ }^{17}$ The difficulties for fixed effects specifications of picking up any existing relationship between a sluggish variable such as LDI and growth will be exacerbated for shorter time series, which might contribute to this non-robust result. Appendix Tables B.7 and B.8 report (fixed effects) models substituting year dummies with the cubic time trend and random effects specifications, respectively. LDI estimated on the post-1960 sample is significant at 1 percent in the former and 5 percent in the latter specification.

${ }^{18}$ In contrast, we do not find clear evidence that local democracy enhances growth in Asia, Latin America, or the Middle East.
} 


\section{Conclusion}

We have argued that local democracy enhances economic growth by facilitating decentralized policymaking and by incentivizing local politicians to select policies that benefit development, including provision of local public goods. Using data from the V-Dem dataset, we tested the relationship between local democracy and growth on an extensive sample covering about 150 countries and a time series extending from 1900 to the present. Whereas we do not find robust relationships for measures of decentralization or of national-level democracy, we do find robust evidence that local democracy predicts GDP per capita growth. This relationship holds when accounting for country- and year-fixed effects, in a variety of plausible specifications, and in GMM models that treat LDI as an endogenous regressor. Further tests reveal that, in accordance with our theory, the relationship is especially strong in (national-level) democracies, in the early decades of the twentieth century in Western countries, and in more recent decades in SubSaharan Africa.

Building on these findings, we suggest several avenues for future research. The first pertains to the causal mechanisms of our theory. In Section I, we identified policies commonly run by local governments that might affect growth performance. Data permitting, one might test the relationship between the character of local institutions and the adoption of alternate policies. (For an initial foray, focused on education policy, see Table B.1.) Second, one might interrogate prior causes. What are the determinants of local democracy? While the sources of national-level democracy (Coppedge 2012; Møller \& Skaaning 2012) and decentralization (Arzaghi \& Henderson 2005; Falleti 2010; Montero \& Samuels 2004) have been extensively probed, the causes of local democracy are less well understood. 


\section{References}

Abramson, Scott F., and Carles Boix. 2014. The Roots of the Industrial Revolution: Political Institutions or (Socially Embedded) Know-How? Unpublished manuscript, Department of Politics, Princeton University.

Acemoglu, Daron. 2005. Politics and Economics in Weak and Strong States. Journal of Monetary Economics 52, 1199-1226.

Acemoglu, Daron. 2009 Introduction to Modern Economic Growth. Princeton: Princeton University Press.

Acemoglu, Daron, Suresh Naidu, Pascual Restrepo, and James A. Robinson. 2015. Democracy

Does Cause Growth. Unpublished manuscript. Department of Economics, MIT.

Alesina, Alberto, and Roberto Perotti. 1997. The Politics of Growth: A Survey. In Government and Growth, ed. V. Bergstrom. Oxford: Clarendon.

Arzaghi, Mohammad, Vernon Henderson. 2005. "Why Countries are Fiscally Decentralizing." Journal of Public Economics 89:7, 1157-89

Ashworth, Scott. 2012. Electoral Accountability: Recent Theoretical and Empirical Work. Annual Review of Political Science 15: 183-201.

Bardhan, Pranab. 2002. Decentralization of Governance and Development. Journal of Economic Perspectives 16: 4: 185-205.

Bardhan, Pranab, and Dilip Mookherjee. 2000. Capture and Governance at Local and National Levels. American Economic Review 90: 2: 135-9.

Bardhan, Pranab, and Dilip Mookherjee, eds. 2006. Decentralization and Local Governance in Developing Countries: A Comparative Perspective. Cambridge: MIT Press.

Barro, Robert. 1996. Democracy and Growth. Journal of Economic Growth 1: March: 1-27.

Barro, Robert, and Xavier Sala-i-Martin. 2004. Economic Growth. Cambridge, MA: MIT Press.

Barro, Robert, and Jong-Wha Lee. 2013. A New Data Set of Educational Attainment in the World, 1950-2010. Journal of Development Economics 104: September: 184-98.

Barzel, Yoram. 2002. A Theory of the State: Economic Rights, Legal Rights, and the Scope of the State. Cambridge: Cambridge University Press.

Baskaran, Thushyanthan, Lars P. Feld, and Jan Schnellenbach. 2016. Fiscal Federalism, Decentralization, and Economic Growth: A Meta-Analysis. Economic Inquiry 54: 2.

Bates, Robert H. 2008. When Things Fell Apart: State Failure in Late-Century Africa. Cambridge: Cambridge University Press. 
Besley, Timothy, and Marta Reynal-Querol. 2011. Do Democracies Select More Educated Leaders? American Political Science Review 105: 3: 552-66.

Besley, Timothy, and Stephen Coate. 2003. Centralized versus Decentralized Provision of Local Public Goods: A Political Economy Approach. Journal of Public Economy 87: 2611-37.

Besley, Timothy. 2005. Political Selection. Journal of Economic Perspectives 19: 3: 43-60.

Bierschenk, Thomas, and Jean-Pierre Olivier de Sardan. 1997. Local Powers and a Distant State in Rural Central African Republic. Journal of Modern African Studies 35: 3: 441-68.

Blair, H. 2000. Participation and Accountability at the Periphery: Democratic Local Governance in Six Countries. World Development 28: 1: 21-39.

Blundell, Richard, and Stephen Bond. 1998. Initial Conditions and Moment Restrictions in Dynamic Panel Data Models. Journal of Econometrics 87: 115-43.

Boix, Carles, Michael Miller, and Sebastian Rosato. 2013. A Complete Dataset of Political Regimes, 1800-2007. Comparative Political Studies 46: 12: 1523-54.

Bolt, Jutta, and Jan Luiten van Zanden. 2013. The First Update of the Maddison Project: Reestimating Growth before 1820. Maddison-Project Working Paper No. 4.

Bosker, Marteen, EltjoBuringh, Jan L. and van Zanden. 2013. From Baghdad to London: Unravelling Urban Development in Europe, the Middle East and North Africa, 800-1800. The Review of Economics and Statistics 95:4, 1418-37.

Brunetti, Aymo. 1997. Political Variables in Cross-Country Analysis. Journal of Economic Surveys 11: 2: 163-90.

Bueno de Mesquita, Bruce, and Hilton L. Root, eds. 2000. Governing for Prosperity. New Haven: Yale University Press.

Carter, David, and Signorino. 2010. Back to the Future: Modeling Time Dependence in Binary Data. Political Analysis 18: 3: 271-292.

Coppedge, Michael. 2012. Democratization and Research Methods. Cambridge: Cambridge University Press.

Coppedge, Michael, John Gerring, Staffan I. Lindberg, Svend-Erik Skaaning, Jan Teorell, David Altman, Frida Andersson, Michael Bernhard, M. Steven Fish, Adam Glynn, Allen Hicken, Carl Henrik Knutsen, Kyle L. Marquardt, Kelly McMann, Valeriya Mechkova, Farhad Miri, Pamela Paxton, Josefine Pernes, Daniel Pemstein, Jeffrey Staton, Natalia Stepanova, Eitan Tzelgov, Yi-ting Wang, and Brigitte Zimmerman. 2016. "V-Dem Country-Year Dataset v5." Varieties of Democracy (V-Dem) Project.

Coppedge, Michael, John Gerring, Staffan I. Lindberg, Svend-Erik Skaaning, Jan Teorell, David Altman, Frida Andersson, Michael Bernhard, M. Steven Fish, Adam Glynn, Allen Hicken, 
Carl Henrik Knutsen, Kelly McMann, Valeriya Mechkova, Farhad Miri, Pamela Paxton, Daniel Pemstein, Rachel Sigman, Jeffrey Staton, and Brigitte Zimmerman. 2016. "V-Dem Codebook v5." Varieties of Democracy (V-Dem) Project.

Coppedge, Michael, John Gerring, Staffan I. Lindberg, Jan Teorell, David Altman, Michael Bernhard, M. Steven Fish, Adam Glynn, Allen Hicken, Carl Henrik Knutsen, Kelly McMann, Daniel Pemstein, Megan Reif, Svend-Erik Skaaning, Jeffrey Staton, Eitan Tzelgov, Yi-ting Wang, and Brigitte Zimmerman. 2016. Varieties of Democracy: Methodology v5. Varieties of Democracy (V-Dem) Project.

Crook, Richard C., and James Manor. 1998. Democracy and Decentralization: Local Government in South Asia and West Africa. Cambridge: Cambridge University Press.

Dawson, John W. 1999. Institutions, Investment and Growth: New Cross-Country and Panel Data Evidence. Economic Inquiry 36: 603-19.

de Haan, Jakob, and Clemens L.J. Siermann. 1995a. New Evidence on the Relationship between Democracy and Economic Growth. Public Choice 86: January: 175-98.

de Haan, Jakob, and Clemens L.J. Siermann. 1995b. A Sensitivity Analysis of the Impact of Democracy on Economic Growth. Empirical Economics 20: 197-215.

Dickovick, J. Tyler. 2011. Decentralization and Recentralization in the Developing World: Comparative Studies from Africa and Latin America. University Park: Penn State Press.

Doucouliagos, Hristos, and Mehmet Ulubasoglu. 2008. Democracy and Economic Growth: A Meta-Analysis. American Journal of Political Science 52: 1: 61-83.

Echeverri-Gent, John. 1993. The State and the Poor: Public Policy and Political Development in India and the United States. Berkeley: University of California Press.

Englebert, Pierre. 2002. State Legitimacy and Development in Africa. Boulder, CO: Lynne Rienner.

Enikolopov, Ruben, and Ekaterina Zhuravskaya. 2007. Decentralization and Political Institutions. Journal of Public Economics 91: 11-12: 2261-2290.

Faguet, Jean-Paul, and Caroline Pöschl, eds. 2015. Is Decentralization Good For Development? Perspectives from Academics and Policy Makers. Oxford: Oxford University Press.

Falleti, Tulia G. 2010. Decentralization and Subnational Politics in Latin America. New York: Cambridge University Press.

Faust, Jörg. 2007. Democracy's Dividend: Political Order and Economic Productivity. World Political Science Review 3: 2: 1-26.

Feng, Yi. 1997. Democracy, Political Stability and Economic Growth. British Journal of Political Science 27: 3: 391-418. 
Feng, Yi. 2003. Democracy, Governance, and Economic Performance: Theory and Evidence. Cambridge: MIT Press.

Ferejohn, John. 1986. Incumbent Performance and Electoral Control. Public Choice 50: 5-26.

Ferraz, Claudio, and Frederico Finan. 2011. Electoral Accountability and Corruption: Evidence from the Audits of Local Governments. American Economic Review 101: 4: 1274-1311.

Gasiorowski, Mark J. 2000. Democracy and Macroeconomic Performance in Underdeveloped Countries: An Empirical Analysis. Comparative Political Studies 33: April: 319-49.

Gelineau Francois, and Karen Remmer. 2006. Political Decentralization and Electoral Accountability: The Argentine Experience, 1983-2001. British Journal of Political Science 36: 1: $133-57$.

Gemmell, Norman, Richard Kneller, and Ismael Sanz. 2013. Fiscal Decentralization and Economic Growth: Spending versus Revenue Decentralization. Economic Inquiry 51: 1915-31.

Gerring, John, Philip Bond, William Barndt, and Carola Moreno. 2005. Democracy and Growth: A Historical Perspective. World Politics 57: 3: 323-64.

Gerring, John, Maxwell Palmer, Jan Teorell, and Dominic Zarecki. 2015. Demography and Democracy: A Global, District-level Analysis of Electoral Contestation. American Political Science Review 109: 3: 574-91.

Gerring, John, and Strom Thacker. 2008. A Centripetal Theory of Democratic Governance. Cambridge: Cambridge University Press.

Giavazzi, Francesco, and Guido Tabellini. 2005. Economic and Political Liberalizations. Journal of Monetary Economics 52: 7: 1297-1330.

Giuliano, Paola, and Nathan Nunn. 2013. The Transmission of Democracy: From the Village to the Nation-State. American Economic Review 103: 3: 86-92.

Guiso, Luigi, Paolo Sapienza, and Luigi Zingales. 2008. Long Term Persistence. NBER Working Paper 14278.

Haber, Stephen, and Victor Menaldo. 2010. Do Natural Resources Fuel Authoritarianism? A Reappraisal of the Resource Curse. American Political Science Review 105: 1: 1-24.

Haider-Markel, Donald P. 2014. The Oxford Handbook of State and Local Government. Oxford: Oxford University Press.

Hankla, Charles, and William Downs. 2010. Decentralization, Governance, and the Structure of Local Political Institutions: Lessons for Reform? Local Government Studies 36: 6: 759-83.

Hankla. Charles R. 2009. When is Fiscal Decentralization Good for Governance? Publius: The Journal of Federalism 39: 4: 632-50. 
Hanushek, Eric A., and Ludger Woessmann. 2008. The Role of Cognitive Skills in Economic Development. Journal of Economic Literature 46: 3: 607-68.

Hanushek, Eric A., and Ludger Woessmann. 2012. Do Better Schools Lead to More Growth? Cognitive Skills, Economic Outcomes, and Causation. Journal of Economic Growth 17: 4: 267321.

Harding, Robin. 2015. Attribution and Accountability: Voting for Roads in Ghana. World Politics 67: 4: 656-89.

Hausmann, Ricardo, Lant Pritchett, and Dani Rodrik. 2005. Growth Accelerations. Journal of Economic Growth 10: 4: 303-29.

Helliwell, John. 1994. Empirical Linkages between Democracy and Economic Growth. British Journal of Political Science 24: 225-48.

Inman, Robert P., and Daniel L. Rubinfeld. 1997. Rethinking Federalism. Journal of Economic Perspectives 11: 4: 43-64.

Jacob, Marcus. 2010. Long-Term Persistence: The Free and Imperial City Experience in Germany. EBS University Oestrich-Winkel. Working Paper.

Jamison, Eliot A, Dean T. Jamison, and Eric A Hanushek. 2007. The Effects of Education Quality on Income Growth and Mortality Decline. Economics of Education Review 26: 6: 771-88.

Khemani, Stuti. 2001. Decentralization and Accountability: Are Voters More Vigilant in Local than in National Elections? Policy Research Working Paper No. 2557, Development Research Group, The World Bank.

Knutsen, Carl Henrik. 2012. Democracy and Economic Growth: A Survey of Arguments and Results. International Area Studies Review 15: 4: 393-415.

Knutsen, Carl Henrik. 2015. Why Democracies Outgrow Autocracies in the Long Run: Civil Liberties, Information Flows, and Technological Change. Kyklos 68: 3: 357-84.

Knutsen, Carl Henrik, Andreas Kotsadam, Eivind Hammersmark Olsen, and Tore Wig. 2016. Mining and Local Corruption in Africa. American Journal of Political Science. First View: 1-15.

Konitzer, Andrew, and Stephen K. Wegren. 2006. Federalism and Political Recentralization in the Russian Federation: United Russia As the Party of Power. Publius 36: 4: 503-22.

Krieckhaus, Jonathan. 2004. The Regime Debate Revisited: A Sensitivity Analysis of Democracy's Effects. British Journal of Political Science 34: 4: 635-55.

Krugman, Paul. 1991. Geography and Trade. Cambridge, MA: The MIT Press.

Kurzman, Charles K., Regina W. Werum, and Ross E. Burkhart. 2002. Democracy's Effect on Economic Growth: A Pooled Time-Series Analysis, 1951-1980. Studies in Comparative International Development 37: 1: 3-33. 
Levy, Jonah D. 1999. Tocqueville's Revenge: State, Society, and Economy in Contemporary France. Cambridge: Harvard University Press.

Lindert, Peter H. 2004. Growing Public: Social Spending and Economic Growth Since the Eighteenth Century, Volume I: The Story. New York: Cambridge University Press.

Mankiw, Gregory N., David Romer, and David N. Weil. 1992. A Contribution to the Empirics on Economic Growth. Quarterly Journal of Economics 107: 2: 407-37.

Marshall, Monty, Ted Gurr, Keith Jaggers. 2014. Polity IV project: Dataset users' manual. http://www.systemicpeace.org/inscr/p4manualv2013.pdf

Martinez-Bravo, Monica, Gerard Padró i Miquel, Nancy Qian, and Yang Yao. 2014. Political Reform in China: Elections, Public Goods and Income Distribution. Manuscript.

Martinez-Vazquez, Jorge, and Robert M. McNab. 2003. Fiscal Decentralization and Economic Growth. World Development 31: 9: 1597-1616.

McMann, Kelly M. 2016. Measuring Subnational Democracy. Varieties of Democracy Institute: Working Paper Series, No. 26.

Møller, Jørgen, Svend-Erik Skaaning. 2012. Democracy and Democratization in Comparative Perspective: Conceptions, Conjunctures, Causes and Consequences. London: Routledge.

Montero, Alfred P., David J. Samuels (eds). 2004. Decentralization and Democracy in Latin America. South Bend: University of Notre Dame Press.

Mookherjee, Dilip. 2015. Political Decentralization. Annual Review of Economics 7: 231-49.

Moricz, Sara, and Fredrik Sjöholm. 2014. The Effect of Elections on Economic Growth: Results from a Natural Experiment in Indonesia. IFN Working Paper No. 1023. Available at SSRN:http://ssrn.com/abstract $=2475930$

Munck, Gerardo L. 2009. Measuring Democracy: A Bridge between Scholarship and Politics. Baltimore: John Hopkins University Press

Norris, Pippa. 2012. Making Democratic Governance Work: How Regimes Shape Prosperity, Welfare, and Peace. Cambridge: Cambridge University Press.

North, Douglass C. 1990. Institutions, Institutional Change and Economic Performance. Cambridge: Cambridge University Press.

Oates, Wallace E. 1972. Fiscal Federalism. New York: Harcourt Brace Jovanovich.

Oppenheimer, Danny, and Mike Edwards. 2012. Democracy Despite Itself: Why a System That Shouldn't Work at All Works So Well. Cambridge: MIT Press.

Oxhorn, Philip, Joseph S. Tulchin, and Andrew D. Selee, eds. 2004. Decentralization, Democratic Governance, and Civil Society in Comparative perspective: Africa, Asia, and Latin America. Baltimore: Johns Hopkins University Press. 
Papaioannou, Elias, and Gregorios Siourounis. 2008. Democratization and Growth. Economic Journal 118: October: 1520-51.

Pemstein, Daniel, Kyle L. Marquardt, Eitan Tzelgov, Yi-ting Wang, and Farhad Miri. 2015. The V-Dem Measurement Model: Latent Variable Analysis for Cross-National and CrossTemporal Expert-Coded Data. Varieties of Democracy Institute: Working Paper Series, No. 21. Ponce-Rodriguez, Raul, Charles R. Hankla, Jorge Martinez-Vazquez, and Eunice Heredia-Ortiz. 2016. Rethinking the Political Economy of Decentralization: How Elections and Parties Shape the Provision of Local Public Goods. GEN Working Paper A 2016 - 3.

Powell, Jr., G. Bingham, and Guy D. Whitten. 1993. A Cross-National Analysis of Economic Voting: Taking Account of the Political Context. American Journal of Political Science 37: 2: 391414.

Przeworski, Adam, and Fernando Limongi. 1993. Political Regimes and Economic Growth. Journal of Economic Perspectives 7: 3: 51-69.

Przeworski, Adam, Michael E. Alvarez, José Antonio Cheibub, and Fernando Limongi. 2000. Democracy and Development: Political Institutions and Well-Being in the World, 1950-1990. Cambridge: Cambridge University Press.

Rodden, Jonathan. 2004. Comparative Federalism and Decentralization: On Meaning and Measurement. Comparative Politics 36: 4: 481-500.

Romer, Paul. 1990. Endogenous Technological Change. Journal of Political Economy 98: 2: 71-102.

Roodman, David. 2009. A Note on the Theme of too many Instruments. Oxford Bulletin of Economics and Statistics 71: 1: 135-58.

Shleifer, Andrei, and Robert W. Vishny. 1993. Corruption. Quarterly Journal of Economics 108: 3: $599-617$.

Solow, Robert. 1956. A Contribution to the Theory of Economic Growth. The Quarterly Journal of Economics 70: 1: 65-94.

Somanathan, E. 2001. Empowering Local Government: Lessons from Europe. Economic and Political Weekly 36: 41: 3935-40.

Stasavage, David. 2005. Democracy and Primary Education in Africa. American Journal of Political Science 49: 2: 343-35.

Tavares, Jose, and Romain Wacziarg. 2001. How Democracy Affects Growth. European Economic Review 45: 8: 1341-78.

Teorell, Jan, Michael Coppedge, Sven-Erik Skaaning, and Staffan I. Lindberg. 2016. Measuring Electoral Democracy with V-Dem Data: Introducing a New Polyarchy Index. Varieties of Democracy Institute: Working Paper No. 25. 
Tiebout, Charles M. 1956. A Pure Theory of Local Government Expenditure. Journal of Political Economy 64: 416-24.

Treisman, Daniel S. 2007. The Architecture of Government: Rethinking Political Decentralization. Cambridge: Cambridge University Press.

Tsai, Lily Lee. 2007. Accountability without Democracy: How Solidary Groups Provide Public Goods in Rural China. Cambridge: Cambridge University Press.

Vanhanen, Tatu. 2000. A New Dataset for Measuring Democracy, 1810-1998. Journal of Peace Research 37: 251-65.

Weingast, Barry R. 1995. The Economic Role of Political Institutions: Market-Preserving Federalism and Economic Development. Journal of Law, Economics, and Organization 11: 1: 1-31.

White, Tracey. 2011. Government Decentralization in the 21 ${ }^{\text {st }}$ Century. Washington D.C.: Center for Strategic and International Studies.

Wig, Tore. 2015. Beyond the Civil Democratic Peace: Subnational Political Institutions and Internal Armed Conflict. Oslo: University of Oslo. PhD Thesis.

Wittman, Donald A. 1995. The Myth of Democratic Failure: Why Political Institutions are Efficient. Chicago: University of Chicago Press.

Zanden, Jan van, Eltjo Buringh, and Maarten Bosker. 2012. The Rise and Decline of European Parliaments, 1188-1789. The Economic History Review 65: 3: 835-861.

Ziblatt, Daniel. 2008. Does Landholding Inequality Block Democratization? The "Bread and Democracy" Thesis and the Case of Prussia. World Politics 60: 4: 610-41. 


\section{Appendix A: Data and measures}

Local Democracy Index (LDI). This index is constructed by first re-scaling v2ellocelc, v2elffelr, and v2ellocpwr to range from $0-1$, and then taking the product of these three indicators.

Local Elections (v2ellocelc). Question: At the local level, are government (local government) offices elected in practice? The clarification in the V-Dem codebook states that "Government offices" here refers to a local executive and a local assembly, not a judiciary and not minor bureaucrats. An executive is a single individual (or a very small group) (e.g., a mayor). An assembly is a larger body of officials. "Elected" refers to offices that are directly elected by citizens or indirectly elected by a local elected assembly. All other methods of obtaining office - including appointment by a higher level of government - are considered to be non-elected. In classifying a position as elected one is making no judgments about the freeness/fairness of the election or the relative extent of suffrage. One is simply indicating that there is an election and that the winner of that election (however conducted) generally takes office." The version of v2ellocelc that we employ follow the same procedure as McMann (2016) does when creating the V-Dem Local Government Index, in that the original V-Dem categories are first recoded so that $0=$ neither executive nor assembly is elected, $1=$ only executive elected, $2=$ only assembly elected, and $3=$ both elected. Source: V-Dem (Coppedge et al. 2016).

Local Elected Offices Relative Power (v2ellocpwr). Excerpt from the V-Dem codebook: "Question: How would you characterize the relative power, in practice, of elected and nonelected offices at the local level? Clarification: We are concerned with the relative power of local offices to each other, not the power of local offices relative to higher levels of government. Please consider only major offices, such as the executive, assembly, and judiciary, not those of minor bureaucrats. (A body of government officials, such as an assembly or judiciary, counts as one office.) An office is "subordinate" if its officeholders can be chosen and removed by another office or if its decisions can be blocked or modified by another office, but it cannot similarly constrain the other office. Responses: 0: All or nearly all elected offices are subordinate to non-elected offices at the local level. 1: Some elected offices are subordinate to non-elected offices at the local level. 2: Elected and non-elected offices are approximately equal in power at the local level. 3: Most non-elected offices are subordinate to elected offices at the local level. 4: All or nearly all non-elected offices are subordinate to elected offices at the local level. Ordering: Skip if previous question coded as " 0 " Scale: Ordinal, converted to interval by the measurement model. Crosscoder aggregation: Bayesian item response theory measurement model” Source: V-Dem (Coppedge et al. 2016).

Free and Fair Subnational Elections (v2elffelr). Excerpt from the V-Dem codebook: "Question: Taking all aspects of the pre-election period, election day, and the post-election process into account, would you consider subnational elections (regional and local, as previously identified) to be free and fair on average? Clarification: This question refers to subnational levels that have elected offices and elections. It does not refer to subnational levels without elected offices and elections. If there were no subnational elections in any of the years covered in this survey, choose option 5. "Free and fair" refers to all aspects of the election process except the extent of suffrage (by law). Thus, a free and fair election may occur even if the law excludes significant groups (we measure that issue separately). Responses: 0: No, not at all. The elections were fundamentally flawed and the official results had little if anything to do with the 'will of the people' (who won office). 1: Not really. While the elections allowed for some competition, the irregularities in the end affected the outcome of the elections (who won office). 2: Ambiguous. There was substantial competition and freedom of participation but there were also significant irregularities. It is hard to determine whether the irregularities affected the outcome or not (who won office). 3: Yes, somewhat. There were deficiencies and some degree of fraud and irregularities but these did not in the end 
affect the outcome (who won office). 4: Yes. There was some amount of human error and logistical restrictions but these were largely unintentional and without significant consequences. Scale: Ordinal, converted to interval by the measurement model. Note: As of December 2014, the former category " 5 " is recoded as a separate variable (v2elffelrbin). Cross-coder aggregation: Bayesian item response theory measurement model" Source: V-Dem (Coppedge et al. 2016).

Ln GDP per capita (e_migdppcln). Real PPP-adjusted Gross domestic product per capita, transformed by the natural logarithm. Source: Maddison Project (Bolt and van Zanden 2014).

GDP per capita growth (e_migdpgro). Annual growth rate of real PPP-adjusted GDP per capita. Source: Maddison Project (Bolt and van Zanden 2014).

Federalism (federalism_GT). An institutionalized division or sharing of responsibilities between a national authority and semiautonomous regional units, usually codified in a constitution. $0=$ nonfederal (regional governments, if they exist, are granted minimal policy-making power), $1=$ semifederal (there are elective governments at the regional level but constitutional sovereignty is reserved to the national government), $2=$ federal (elective regional governments plus constitutional recognition of subnational authority). Rescaled from 0-1. Source: Gerring and Thacker (2008: 88).

Revenue decentralization (Decentraliz_rev_EZ). Subnational revenue as share of total public revenue. Rescaled from 0-1. Source: GFS, as compiled by Enikolopov and Zhuravskaya (2007).

Polyarchy (v2x_polyarchy). The index is formed by taking the average of, on the one hand, the sum of the indices measuring freedom of association (thick) (v2x_frassoc_thick), suffrage (v2x_suffr), clean elections (v2xel_frefair), elected executive (de jure) (v2x_accex) and freedom of expression (v2x_freexp_thick); and, on the other, the five-way interaction between those indices. Source: V-Dem (Coppedge et al. 2016).

Polity 2 (e_polity2). A weighted additive aggregation procedure across five sub-components: competitiveness and openness of executive recruitment, competitiveness and regulation of political participation, and constraints on the chief executive. Source: Polity IV database (Marshall, Gurr, and Jaggers 2014).

Democracy, Boix Miller, Rosato (e_boix_regime). Dichotomous democracy measure based on contestation and participation. Countries coded democratic have (1) political leaders that are chosen through free and fair elections and (2) a minimal level of suffrage. Source: Boix et al. (2013).

Regional Democracy Index (RDI). This index is identically constructed as the Local Democracy Index, but substituting the indicators for Local Elections and Local Elected Offices Relative Power with the corresponding V-Dem variables for Regional Elections and Regional Elected Offices Relative Power.

Subnational Democracy Index (SDI). This index follows the logic of the Local Democracy Index, but includes both regional and local democracy characteristics, which are weighted equally. The index is calculated as following: (1/2(Local Elections* Local Elected Offices Relative Power) + 1/2(Regional Elections* Regional Elected Offices Relative Power))* Free and Fair Subnational Elections.

Ln Population (e_mipopula_ln) Total population, transformed by the natural logarithm. Source: V-Dem (Coppedge et al. 2016), constructed from data from CLIO Infra (clio-infra.eu). For this variable, V-Dem has interpolated missing data on the population count within a time-series using a linear model.

Urbanization (e_miurbani). Ratio of urban population to total population. Source: V-Dem (Coppedge et al. 2016), constructed from data from CLIO Infra (clio-infra.eu).

Civil War (e_Civil_War). A dummy variable coded 1 if there was at least one intra-state war with at least 1,000 
battle deaths in a country-year, and 0 otherwise. Source: Haber and Menaldo (2011).

Fuel income per capita (e_Total_Fuel_Income_P1000C). The measure is scaled so that it counts resource income for 1000 inhabitants rather than per inhabitant. Source: Haber and Menaldo (2011).

Family farms (e_Vanhanen_familyfarm_ipo). What percentage of (cultivated) land area is comprised of family farms? Source: V-Dem (Coppedge et al. 2016), providing a linearly interpolated version of the data originally taken from Vanhanen (2003).

Average years of schooling, 25 year olds (bl_asy $25 \mathrm{mf}$ ). The variable is measured with 5-year intervals. Source: Barro and Lee (2013)

Average years of schooling, 15 year olds (bl_asy15mf). The variable is measured with 5-year intervals. Source: Barro and Lee (2013)

Average years of schooling, 25 year old females (bl_asy25f). The variable is measured with 5-year intervals. Source: Barro and Lee (2013)

Average years of schooling, 15 year old females (bl_asy15f). The variable is measured with 5-year intervals. Source: Barro and Lee (2013) 


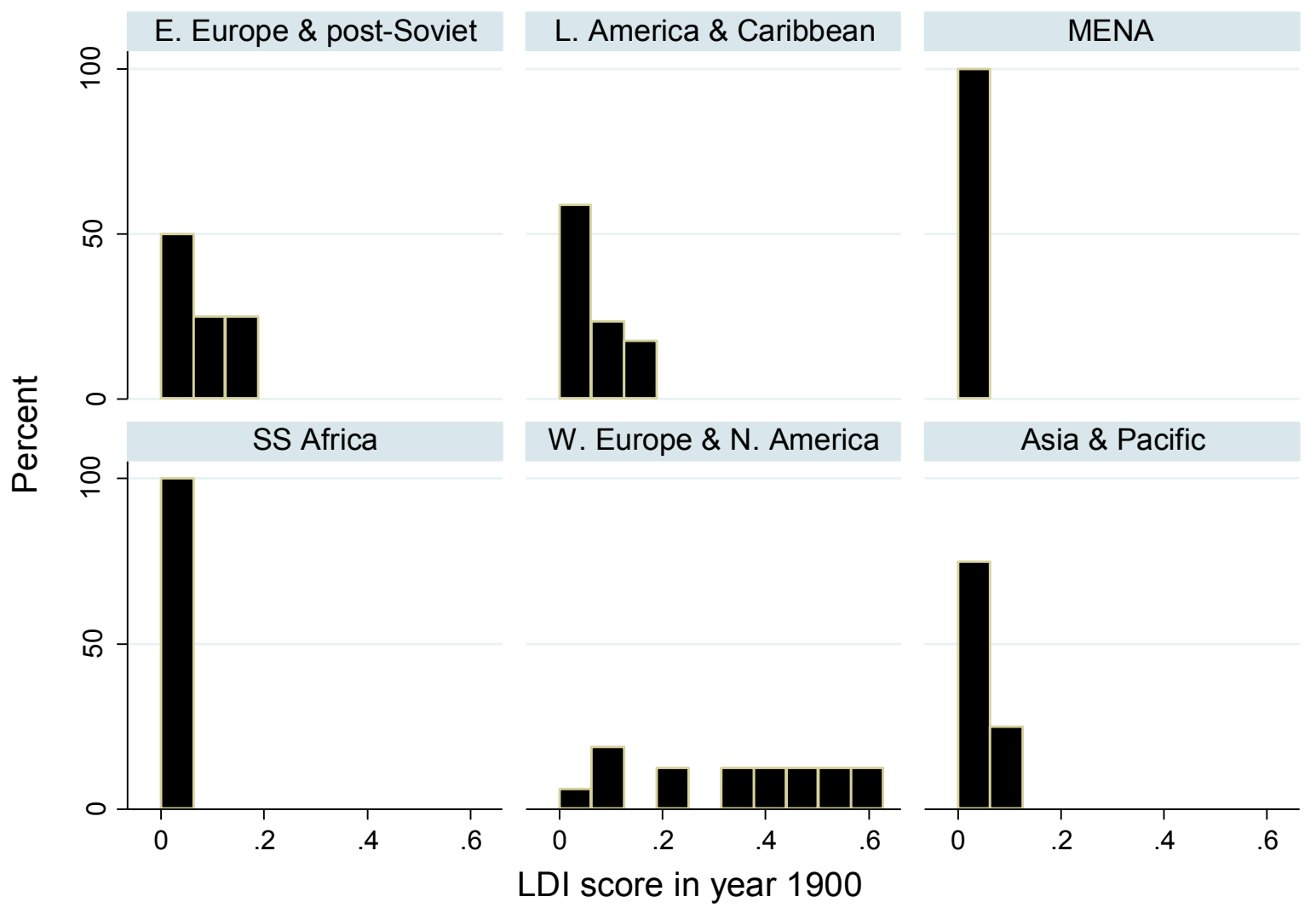

Figure A.1: Histograms over LDI in year 1900, by major world regions 


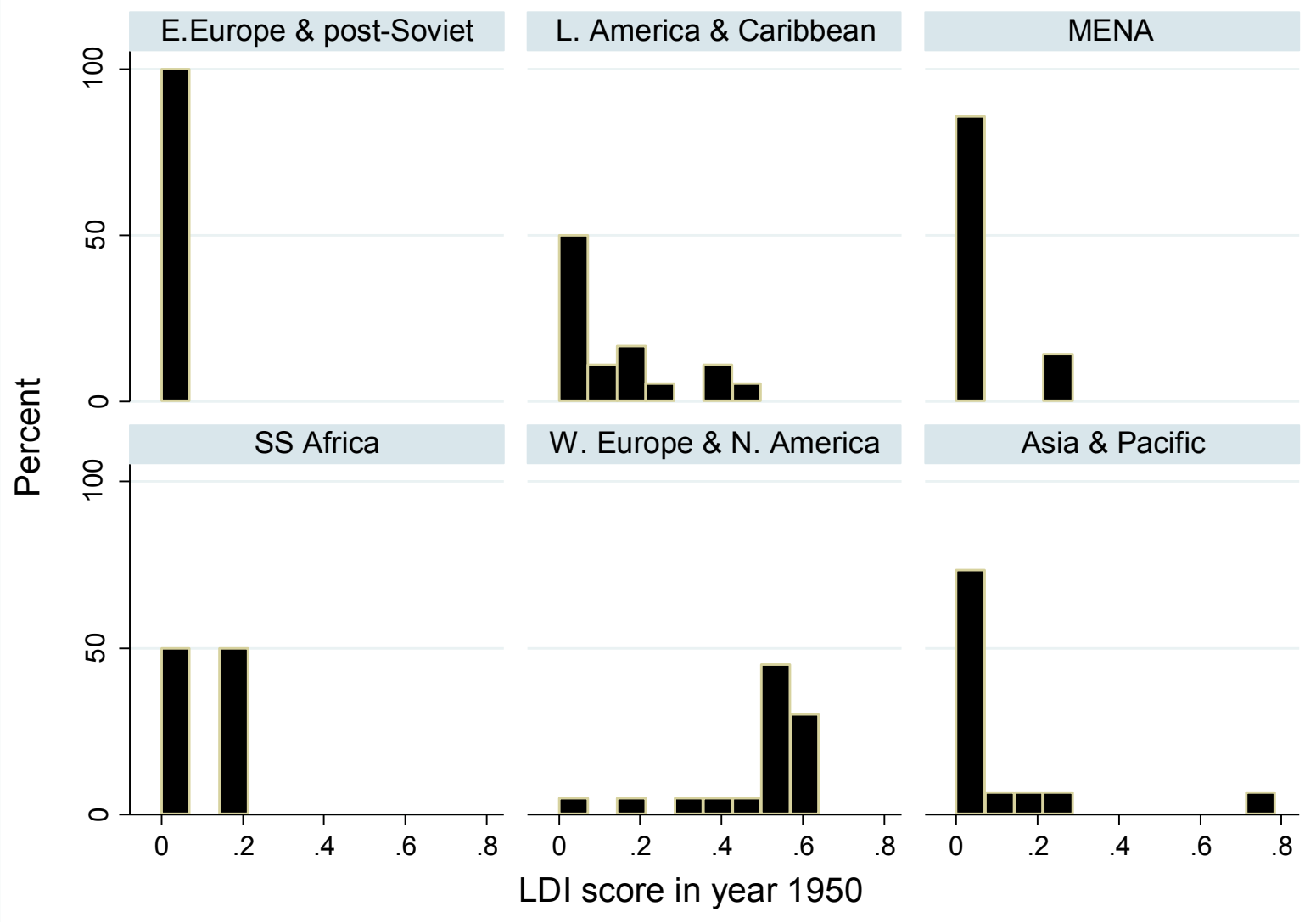

Figure A.2: Histograms over LDI in year 1950, by major world regions 


\section{Appendix B: Additional tests}

Table B.1: Baseline specifications, but with measures of education performance as dependent variable

\begin{tabular}{|c|c|c|c|c|c|c|c|c|}
\hline \multirow[b]{2}{*}{ Local Dem. } & \multicolumn{2}{|c|}{$\begin{array}{l}\text { Avg. years } \\
25 \text { year olds }\end{array}$} & \multicolumn{2}{|c|}{$\begin{array}{l}\text { Avg. years schooling, } \\
15 \text { year olds }\end{array}$} & \multicolumn{2}{|c|}{$\begin{array}{l}\text { Avg. years schooling, } \\
25 \text { year old females }\end{array}$} & \multicolumn{2}{|c|}{$\begin{array}{l}\text { Avg. years schooling, } \\
15 \text { year old females }\end{array}$} \\
\hline & $0.89 *$ & 1.08* & 0.73 & 0.89 & $1.24 * *$ & $1.75^{* * *}$ & $0.93 *$ & $1.27 * *$ \\
\hline & 1.79 & 1.71 & 1.52 & 1.49 & 2.56 & 2.87 & 1.96 & 2.13 \\
\hline \multirow[t]{2}{*}{ Ln GDP pc } & $0.43^{* *}$ & $0.42 * *$ & $0.32 * *$ & $0.31 *$ & $0.72 * * *$ & $0.71 * * *$ & $0.54 * * *$ & $0.53^{* * *}$ \\
\hline & 2.44 & 2.34 & 1.99 & 1.92 & 3.68 & 3.63 & 3.01 & 2.95 \\
\hline \multirow[t]{2}{*}{ Polyarchy } & & -0.20 & & -0.16 & & -0.48 & & -0.31 \\
\hline & & -0.52 & & -0.43 & & -1.22 & & -0.81 \\
\hline Country dum. & $\mathrm{Y}$ & $\mathrm{Y}$ & $\mathrm{Y}$ & $\mathrm{Y}$ & $\mathrm{Y}$ & $\mathrm{Y}$ & $\mathrm{Y}$ & $\mathrm{Y}$ \\
\hline Time dum. & $\mathrm{Y}$ & $\mathrm{Y}$ & $\mathrm{Y}$ & $\mathrm{Y}$ & $\mathrm{Y}$ & $\mathrm{Y}$ & $\mathrm{Y}$ & $\mathrm{Y}$ \\
\hline $\bar{N}$ & 1187 & 1170 & 1187 & 1170 & 1187 & 1170 & 1187 & 1170 \\
\hline Countries & 124 & 124 & 124 & 124 & 124 & 124 & 124 & 124 \\
\hline$T S$ (for $D V)$ & $1950-2010$ & $1950-2010$ & $1950-2010$ & $1950-2010$ & $1950-2010$ & $1950-2010$ & $1950-2010$ & $1950-2010$ \\
\hline$R^{2}$ & 0.89 & 0.89 & 0.89 & 0.89 & 0.87 & 0.87 & 0.88 & 0.88 \\
\hline
\end{tabular}

Notes: ${ }^{*} \mathrm{p}<0.1,{ }^{* *} \mathrm{p}<0.05,{ }^{* * *} \mathrm{p}<0.01$. T-stats are reported directly below regression coefficients in italics. All models are (fixed effects) OLS models with robust errors clustered by country. Dependent variable is taken from the Barro and Lee dataset (Barro and Lee 2013), and is reported in 5-year intervals. Hence, the time series unit is 5-year panel, with all independent variables averaged over a 5-year period. All independent variables are lagged by one 5-year period in all models. Country dummies, year dummies, and constant are omitted 


\section{Table B.2: Horse race tests using alternative measures of decentralization and of national-level democracy}

\begin{tabular}{|c|c|c|c|c|c|c|c|c|}
\hline \multirow[b]{2}{*}{ LDI } & \multicolumn{4}{|c|}{ Horse races with decentralization measures } & \multicolumn{4}{|c|}{ Horse races with national-level democracy measures } \\
\hline & $2.73 *$ & $3.07 *$ & -1.04 & -1.54 & $3.41 * * *$ & $3.91 * * *$ & $3.38 * * *$ & $4.00 * * *$ \\
\hline & 1.73 & 1.81 & -0.57 & -0.83 & 3.21 & 3.58 & 3.15 & 3.61 \\
\hline \multirow[t]{2}{*}{ Federalism } & 0.35 & 0.22 & & & & & & \\
\hline & 1.23 & 0.76 & & & & & & \\
\hline \multirow[t]{2}{*}{ Fiscal Decentr. } & & & 0.03 & 0.04 & & & & \\
\hline & & & 1.26 & 1.41 & & & & \\
\hline \multirow[t]{2}{*}{ Polity 2} & & & & & $-0.05^{*}$ & -0.03 & & \\
\hline & & & & & -1.93 & -1.15 & & \\
\hline \multirow[t]{2}{*}{ BMR } & & & & & & & $-0.68^{* *}$ & $-0.51 *$ \\
\hline & & & & & & & -2.43 & -1.80 \\
\hline \multirow[t]{2}{*}{ Ln GDP p.c. } & $-3.97 * * *$ & $-4.49 * * *$ & $-6.46 * * *$ & $-6.95^{* * *}$ & $-3.14 * * *$ & $-3.47 * * *$ & $-3.18^{* * *}$ & $-3.59 * * *$ \\
\hline & -6.29 & -6.87 & -4.08 & -4.42 & -7.15 & -8.08 & -7.33 & -8.4 \\
\hline Country dum. & $\mathrm{Y}$ & $\mathrm{Y}$ & $\mathrm{Y}$ & $\mathrm{Y}$ & $\mathrm{Y}$ & $\mathrm{Y}$ & $\mathrm{Y}$ & $\mathrm{Y}$ \\
\hline Time dummies & $\mathrm{Y}$ & & $\mathrm{Y}$ & & $\mathrm{Y}$ & & $\mathrm{Y}$ & \\
\hline Cubic time trend & & Y & & Y & & $\mathrm{Y}$ & & $\mathrm{Y}$ \\
\hline$N$ & 4693 & 4693 & 1260 & 1260 & 8266 & 8266 & 8141 & 8141 \\
\hline $\mathrm{R}^{2}$ & 0.14 & 0.04 & 0.1 & 0.06 & 0.12 & 0.03 & 0.12 & 0.03 \\
\hline
\end{tabular}

Notes: ${ }^{*} \mathrm{p}<0.1,{ }^{* *} \mathrm{p}<0.05,{ }^{* * *} \mathrm{p}<0.01$. T-stats are reported directly below regression coefficients in italics. All models are (fixed effects) OLS models with robust errors clustered by country. GDP per capita growth is the dependent variable in all models. Independent variables are measured in $\mathrm{t}-3$. Country dummies, year dummies, time trend polynomials, and constant are omitted 
Table B.3: Benchmark specification including different lags of the dependent variable to account for persistence of economic growth (Note that dependent variable always measured in $t+3$, as in benchmark)

\begin{tabular}{|c|c|c|c|c|c|c|}
\hline \multirow[b]{2}{*}{ LDI (t) } & \multirow{2}{*}{$\begin{array}{l}\text { Baseline } \\
2.06^{* *}\end{array}$} & \multicolumn{5}{|c|}{ Alternative specific. incl. various lags of the DV (growth in $t+3$ ) } \\
\hline & & $1.54 *$ & $1.91 * *$ & $1.94 * *$ & $1.97 * *$ & $1.52 *$ \\
\hline & 2.09 & 1.84 & 2.04 & 2.03 & 2.08 & 1.84 \\
\hline \multirow[t]{2}{*}{ Ln GDP p.c. $(t)$} & $-2.84 * * *$ & $-2.39 * * *$ & $-2.75^{* * *}$ & $-2.67 * * *$ & $-2.79 * * *$ & $-2.37 * * *$ \\
\hline & -6.61 & -6.20 & -6.8 & -6.60 & -6.84 & -6.52 \\
\hline \multirow[t]{2}{*}{$\mathrm{DV}$ in $\mathrm{t}+2$} & & $0.12^{* * *}$ & & & & $0.11^{* * *}$ \\
\hline & & 4.20 & & & & 3.77 \\
\hline \multirow[t]{2}{*}{$\mathrm{DV}$ in $\mathrm{t}+1$} & & $0.04 * *$ & & & & 0.03 \\
\hline & & 1.99 & & & & 1.60 \\
\hline \multirow[t]{2}{*}{$\mathrm{DV}$ in $\mathrm{t}$} & & $0.03^{*}$ & $0.04 * *$ & & & 0.03 \\
\hline & & 1.84 & 2.40 & & & 1.60 \\
\hline \multirow[t]{2}{*}{ DV in $\mathrm{t}-1$} & & & $0.02 *$ & $0.03 * *$ & $0.02 *$ & 0.02 \\
\hline & & & 1.72 & 2.08 & 1.73 & 1.24 \\
\hline \multirow[t]{2}{*}{$\mathrm{DV}$ in $\mathrm{t}-2$} & & & -0.01 & -0.01 & -0.01 & -0.01 \\
\hline & & & -0.45 & -0.37 & -0.47 & -0.61 \\
\hline \multirow[t]{2}{*}{ DV in $t-3$} & & & & & 0.01 & \\
\hline & & & & & 0.57 & \\
\hline \multirow[t]{2}{*}{ DV in $\mathrm{t}-4$} & & & & & 0.01 & \\
\hline & & & & & 0.67 & \\
\hline \multirow[t]{2}{*}{ DV in $t-5$} & & & & & 0.01 & \\
\hline & & & & & 0.87 & \\
\hline Country dummies & $\mathrm{Y}$ & $\mathrm{Y}$ & $\mathrm{Y}$ & $\mathrm{Y}$ & $\mathrm{Y}$ & $\mathrm{Y}$ \\
\hline Year dummies & $\mathrm{Y}$ & $\mathrm{Y}$ & $\mathrm{Y}$ & $\mathrm{Y}$ & $\mathrm{Y}$ & $\mathrm{Y}$ \\
\hline$N$ & 9231 & 9126 & 8920 & 8920 & 8604 & 8920 \\
\hline$R^{2}$ & 0.11 & 0.13 & 0.11 & 0.11 & 0.11 & 0.12 \\
\hline
\end{tabular}

Notes: ${ }^{*} \mathrm{p}<0.1,{ }^{* *} \mathrm{p}<0.05,{ }^{* * *} \mathrm{p}<0.01$. T-stats are reported directly below regression coefficients in italics. All models are (fixed effects) OLS models with robust errors clustered by country. GDP per capita growth is the dependent variable in all models. Country dummies, year dummies, and constant are omitted. IV= Independent variables. 
Table B.4: Including alternative sets of control variables

\begin{tabular}{|c|c|c|c|c|c|c|c|}
\hline \multirow[b]{2}{*}{ LDI } & \multirow{2}{*}{$\begin{array}{l}\text { Baseline } \\
2.06^{* *}\end{array}$} & \multicolumn{6}{|c|}{ Alternative sets of control variables } \\
\hline & & $1.77 *$ & $2.24 * *$ & $2.33 * *$ & $2.18^{* *}$ & $3.29 * * *$ & $3.21 * *$ \\
\hline & 2.09 & 1.77 & 2.30 & 2.23 & 2.06 & 2.79 & 2.34 \\
\hline \multirow[t]{2}{*}{ Ln GDP per capita } & $-2.84 * * *$ & $-3.09 * * *$ & $-2.69 * * *$ & $-3.20 * * *$ & $-2.93 * * *$ & $-3.76 * * *$ & $-4.54 * * *$ \\
\hline & -6.61 & -6.16 & -6.16 & -7.62 & -6.66 & -7.02 & -6.40 \\
\hline \multirow[t]{2}{*}{ Ln Population } & & $-1.64 * * *$ & & & & & $-1.81 * * *$ \\
\hline & & -3.26 & & & & & -3.23 \\
\hline \multirow[t]{2}{*}{ Urbanization } & & & -2.18 & & & & 0.28 \\
\hline & & & -0.91 & & & & 0.10 \\
\hline \multirow[t]{2}{*}{ Civil War } & & & & $-1.38^{* * *}$ & & & $-1.10^{* * *}$ \\
\hline & & & & -3.00 & & & -2.67 \\
\hline \multirow[t]{2}{*}{ Fuel income per thousand cap } & & & & & $-0.33^{* *}$ & & -0.04 \\
\hline & & & & & -2.10 & & -0.17 \\
\hline \multirow[t]{2}{*}{ Family farms } & & & & & & 0.01 & 0.01 \\
\hline & & & & & & 0.56 & 1.03 \\
\hline \multirow[t]{2}{*}{ Polyarchy } & & & & & & & $-2.69^{* * *}$ \\
\hline & & & & & & & -1.86 \\
\hline \multirow[t]{2}{*}{ Federalism } & & & & & & & 0.22 \\
\hline & & & & & & & 0.62 \\
\hline Country dummies & $\mathrm{Y}$ & Y & $\mathrm{Y}$ & $\mathrm{Y}$ & $\mathrm{Y}$ & Y & $\mathrm{Y}$ \\
\hline Year dummies & $\mathrm{Y}$ & $\mathrm{Y}$ & Y & $\mathrm{Y}$ & $\mathrm{Y}$ & $\mathrm{Y}$ & $\mathrm{Y}$ \\
\hline$N$ & 9231 & 8952 & 8952 & 8208 & 8192 & 6441 & 3744 \\
\hline$R^{2}$ & 0.11 & 0.12 & 0.11 & 0.12 & 0.12 & 0.11 & 0.16 \\
\hline
\end{tabular}

Notes: ${ }^{*} \mathrm{p}<0.1,{ }^{* *} \mathrm{p}<0.05,{ }^{* * *} \mathrm{p}<0.01$. T-stats are reported directly below regression coefficients in italics. All models are (fixed effects) OLS models with robust errors clustered by country. GDP per capita growth is the dependent variable in all models. Independent variables are measured in $\mathrm{t}-3$. Country dummies, year dummies, and constant are omitted 
Table B.5: Different lag-lengths on independent variables

\begin{tabular}{|c|c|c|c|c|c|c|c|}
\hline Ind. var. measured in & $\mathrm{t}+3$ (baseline) & $\mathrm{t}+2$ & $\mathrm{t}+4$ & $\mathrm{t}+8$ & $\mathbf{t}$ & $\mathrm{t}-1$ & t-3 \\
\hline \multirow[t]{2}{*}{ LDI } & $2.06 * *$ & $2.65 * *$ & $1.71 *$ & $1.46^{*}$ & 0.31 & -1.01 & $-1.87 * *$ \\
\hline & 2.09 & 2.57 & 1.75 & 1.84 & 0.31 & -1.11 & -2.30 \\
\hline \multirow[t]{2}{*}{ Ln GDP p.c. } & $-2.84 * * *$ & $-2.86^{* * *}$ & $-2.84^{* * *}$ & $-2.58^{* * *}$ & $1.95^{* * *}$ & $2.77 * * *$ & $3.50 * * *$ \\
\hline & -6.61 & -6.31 & -6.50 & -7.20 & 6.54 & 8.48 & 9.91 \\
\hline Country dummies & $\mathrm{Y}$ & $\mathrm{Y}$ & $\mathrm{Y}$ & $\mathrm{Y}$ & $\mathrm{Y}$ & $\mathrm{Y}$ & Y \\
\hline Year dummies & $\mathrm{Y}$ & $\mathrm{Y}$ & $\mathrm{Y}$ & $\mathrm{Y}$ & $\mathrm{Y}$ & $\mathrm{Y}$ & $\mathrm{Y}$ \\
\hline$N$ & 9231 & 9391 & 9073 & 8448 & 9611 & 9506 & 9301 \\
\hline$R^{2}$ & 0.11 & 0.11 & 0.11 & 0.11 & 0.11 & 0.12 & 0.12 \\
\hline
\end{tabular}

Notes: ${ }^{*} \mathrm{p}<0.1,{ }^{* *} \mathrm{p}<0.05,{ }^{* * *} \mathrm{p}<0.01$. T-stats are reported directly below regression coefficients in italics. All models are (fixed effects) OLS models with robust errors clustered by country. GDP per capita growth is the dependent variable in all models. Country dummies, year dummies, and constant are omitted 
Table B.6: Granger-type tests

\begin{tabular}{|c|c|c|c|c|c|c|}
\hline \multirow{2}{*}{$\begin{array}{l}\text { Dependent variable: } \\
\text { DV measured in: }\end{array}$} & \multicolumn{3}{|c|}{ GDP per capita growth } & \multicolumn{3}{|l|}{$\overline{L D I}$} \\
\hline & $t+1$ & $t+2$ & $t+3$ & $t+1$ & $t+2$ & $t+3$ \\
\hline \multirow{2}{*}{ LDI (measured in $t$ ) } & $2.81 * * *$ & $2.60 * * *$ & $1.96 * *$ & $0.80^{* * *}$ & $0.84 * * *$ & $0.88^{* * *}$ \\
\hline & 2.89 & 2.82 & 2.05 & 39.82 & 49.50 & 63.58 \\
\hline \multirow{2}{*}{ GDP p.c. growth (measured in $t$ ) } & $0.17^{* * *}$ & $0.09 * * *$ & $0.05^{* * *}$ & $-0.00 * *$ & $-0.00 * *$ & $-0.00^{* *}$ \\
\hline & 5.46 & 4.51 & 2.96 & -2.24 & -2.18 & -2.5 \\
\hline \multirow{2}{*}{ Ln GDP p.c. (measured in $t$ ) } & $-2.58 * * *$ & $-2.71 * * *$ & $-2.81 * * *$ & $0.01 *$ & 0.01 & 0.01 \\
\hline & -6.64 & -6.64 & -6.53 & 1.69 & 1.61 & 1.35 \\
\hline Country dummies & $\mathrm{Y}$ & $\mathrm{Y}$ & $\mathrm{Y}$ & $\mathrm{Y}$ & $\mathrm{Y}$ & $\mathrm{Y}$ \\
\hline Year dummies & $\mathrm{Y}$ & $\mathrm{Y}$ & $\mathrm{Y}$ & $\mathrm{Y}$ & $\mathrm{Y}$ & $\mathrm{Y}$ \\
\hline$N$ & 9448 & 9287 & 9126 & 9249 & 9402 & 9488 \\
\hline$R^{2}$ & 0.13 & 0.11 & 0.11 & 0.77 & 0.81 & 0.85 \\
\hline
\end{tabular}

Notes: ${ }^{*} \mathrm{p}<0.1,{ }^{* *} \mathrm{p}<0.05,{ }^{* * *} \mathrm{p}<0.01$. T-stats are reported directly below regression coefficients in italics. All models are (fixed effects) OLS models with robust errors clustered by country. Country dummies, year dummies, and constant are omitted 
Table B.7: Split-sample tests with cubic time trend

\begin{tabular}{lllllll}
\hline \hline Time-period & Unrestricted & Unrestricted & $1900-1960$ & $1900-1960$ & $1960-2014$ & $1960-2014$ \\
Countries & Democracies & Autocracies & Unrestricted & Western & Unrestricted & Sub-Saharan Africa \\
& $\mathbf{1}$ & $\mathbf{2}$ & $\mathbf{3}$ & $\mathbf{4}$ & $\mathbf{5}$ & $\mathbf{6}$ \\
\hline LDI & $2.66^{* * *}$ & -0.37 & $2.63 * *$ & $6.31 * * *$ & $1.97 * *$ & $7.20^{*}$ \\
& 2.88 & -0.21 & 2.39 & 3.97 & 2.35 & 1.74 \\
Ln GDP per capita & $-0.42^{*}$ & 0.16 & $-0.69^{* *}$ & $-3.63^{* * *}$ & $-0.33^{*}$ & -0.50 \\
& -1.69 & 0.75 & -2.43 & -5.51 & -1.89 & -1.36 \\
Country dummies & $\mathrm{Y}$ & $\mathrm{Y}$ & $\mathrm{Y}$ & $\mathrm{Y}$ & $\mathrm{Y}$ & $\mathrm{Y}$ \\
Cubic time trend & $\mathrm{Y}$ & $\mathrm{Y}$ & $\mathrm{Y}$ & $\mathrm{Y}$ & $\mathrm{Y}$ & $\mathrm{Y}$ \\
\hline N & 3593 & 4548 & 3098 & 1138 & 6133 & 1896 \\
Countries & 101 & 121 & 113 & 21 & 149 & 42 \\
Max years & 107 & 100 & 60 & 60 & 48 & 48 \\
\hline \hline
\end{tabular}

Notes: ${ }^{*} \mathrm{p}<0.1,{ }^{* *} \mathrm{p}<0.05,{ }^{* * *} \mathrm{p}<0.01$. T-stats are reported directly below regression coefficients in italics. All models are (fixed effects) OLS models with robust errors clustered by country. GDP per capita growth is the dependent variable in all models. Independent variables are measured three years before dependent variable. Country dummies, year dummies, and constant are omitted. 
Table B.8: Split-sample tests in Random Effects models

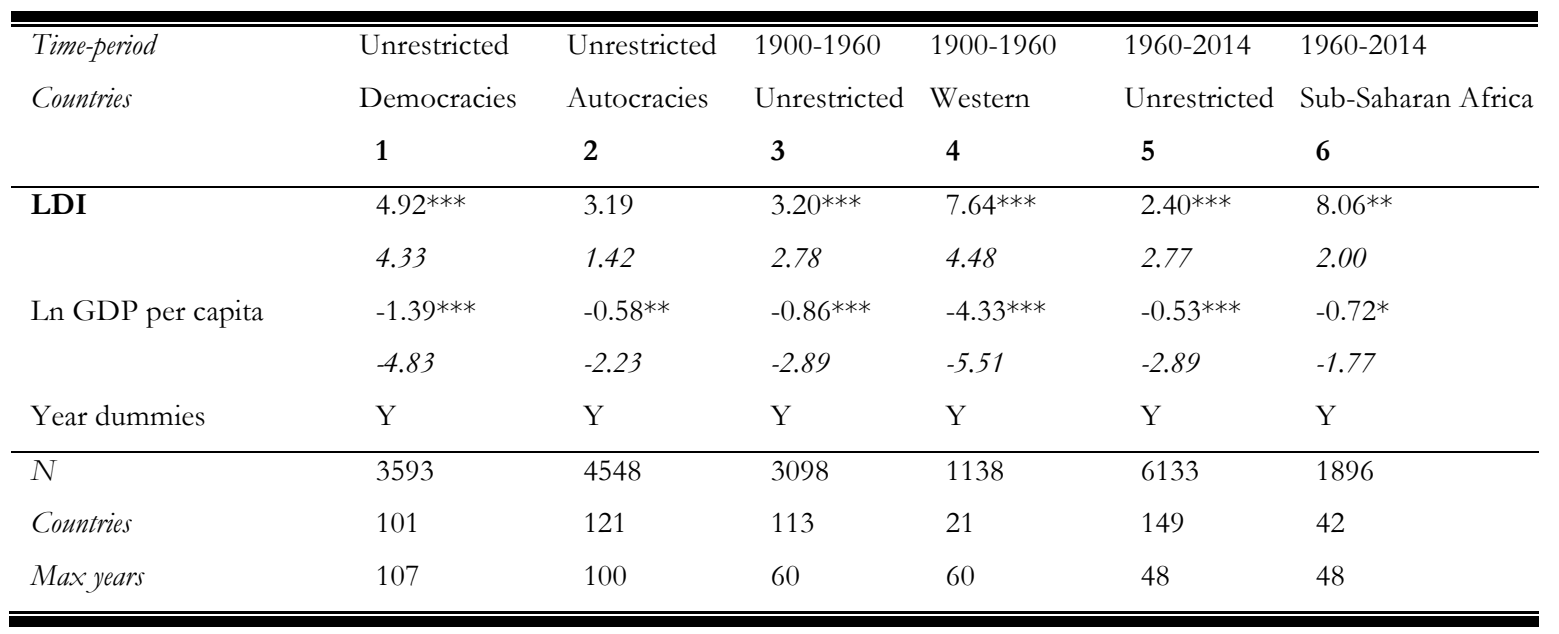

Notes: ${ }^{*} \mathrm{p}<0.1,{ }^{* *} \mathrm{p}<0.05,{ }^{* * *} \mathrm{p}<0.01$. T-stats are reported directly below regression coefficients in italics. All models are Random Effects models with robust errors clustered by country. GDP per capita growth is the dependent variable in all models. Independent variables are measured three years before dependent variable. Year dummies and constant are omitted. 